\title{
PROMOTION AND HARMONIZATION OF ANTITRUST DAMAGES CLAIMS BY DIRECTIVE EU/2014/104?
}

\section{Working Paper IE Law School \\ AJ8-242-I \\ 13-06-2018}

Center for European Studies/IE

Francisco Marcos, Barry J. Rodger and Miguel Sousa Ferro *

\begin{abstract}
Directive EU/2014/104 is the latest legal instrument that crystalizes the evolution of EU competition law enforcement. This paper assesses critically the features of the Directive and the challenges it poses for its implementation by Member States. The Directive codifies the case law of the EUCJ and it encroaches upon the autonomy of Member States in setting the institutions, remedies and procedures available for victims' of antitrust infringements. Although the Directive provides a fragmented and incomplete set of rules that only partially harmonizes antitrust damages claims in the EU, and it's slanted towards follow-on cartel damages claims, it has publicised the availability of damages claims, creating momentum that will transform how competition law is enforced in the future.
\end{abstract}

KEYWORDS: EU competition law, private enforcement, damages claims, harmonization, Directive.

* Draft of Chapter 2 of The EU Antitrust Damages Directive: Transposition in the Member States (Oxford University Press, eds. B. RODGER, M.S. FERRO \& F. MARCOS, due for publication in 2018). 
La publicación de la Serie Jean Monnet Working Papers IE-Law School está patrocinada por el Centro de Excelencia de Estudios Europeos-IE. Copyright (C) 2018 by Francisco Marcos, Professor at IE Law School.

Este working paper se distribuye con fines divulgativos y de discusión.

Prohibida su reproducción sin permiso del autor, a quien debe contactar en caso de solicitar copias.

Editado por el IE Law School e impreso por IE Publishing, Madrid, España.

The publishing of Serie Jean Monnet Working Papers IE-Law School is sponsored by the Center of Excellence of European Studies.

Copyright (C) 2018 by Francisco Marcos, Professor at IE Law School.

This working paper is distributed for purposes of comment and discussion only.

It may not be reproduced without permission of the copyright holder.

Edited by IE Law School and printed at IE Publishing, Madrid, Spain. 


\section{Introduction}

Directive 2014/104/EU is the corollary of the EU's policy regarding the promotion and facilitation of private enforcement of competition law ${ }^{1}$. This paper examines the contents and goals of the Directive and the specific rules adopted while also briefly analysing some of the relevant steps and features of the procedure leading to its adoption. This may help to explain the options and compromises taken in the final version and its scope. Although the Directive's purported aim is to foster compensation of victims of antitrust infringements, it is controversial and there remains uncertainty regarding how effective it might be.

\section{The path to the adoption of the Directive}

The evolution in EU competition law enforcement and policy that led to the adoption of the Directive started more than a decade ago (se Timeline below), during which several relevant milestones were reached, all pointing in the direction that some legislative action of the EU was required.

After the EUCJ judgment in Courage $(1999)^{2}$, the Commission prepared a Green Paper on damages actions for breach of EU competition rules (2005) ${ }^{3}$. The Green Paper built on the evidence provided by the Ashurst report on the legal conditions for damages claims in MS (2004) ${ }^{4}$. In 2006 the CJEU further clarified its position concerning damages claims by victims of EU competition infringements -extending their availability to indirect victims (Manfredi) ${ }^{5}$. An impact assessment with a description of the alternative options was undertaken by the Commission in $2007^{6}$.

\footnotetext{
${ }^{1}$ OJ L 349 of 5 of December 2014. All articles and recitals mentioned in this paper are those of the Directive unless stated otherwise.

${ }^{2}$ Judgment of 20 of September 2001 (Grand Chamber) C-453/99 Courage Ltd v Bernard Crehan and Bernard Crehan v Courage Ltd \& Others (ECLI:EU:C:2001:465).
}

${ }^{3}$ Green Paper on Damages actions for breach of the EC antitrust rules, COM (2005) 652 final and Staff Working Paper Annex to Green Paper Damages actions for breach of EC antitrust rules, COM (2005) 672 final, 19 of December 2005 (hereinafter “Staff Working Paper 2005”).

${ }^{4}$ Denis Waelbroeck, Donald Slater \& Gil Even-Shoshan, Study on the conditions of claims for damages in case of infringement of EC competition rules. Comparative Report, 21 of August 2004 (hereinafter "Ashurst Report 2004")

${ }^{5}$ Judgment of 13 of July 2006 (Third Chamber), Vincenzo Manfredi v Lloyd Adriatico Assicurazioni SpA (C295/04), Antonio Cannito v Fondiaria Sai SpA (C-296/04) \& Nicolò Tricarico (C-297/04) \& Pasqualina Murgolo (C-298/04) v Assitalia SpA (ECLI:EU:C:2006:461).

${ }^{6}$ Making antitrust damages actions more effective in the EU: welfare impact and potential scenarios. Final Report, CEPS-EUR-LUISS, 21 of December 2007 (heinafter 2007 Impact Assessment) 
The Commission approved a White Paper in $2009^{7}$, which led to discussion of an unofficial proposal of a Council Directive on rules governing damages actions for infringements of Articles 101 and 102 of Treaty on the Functioning of the EU (TFEU) ${ }^{8}$. This proposal, presented in the aftermath of Neelie Kroes' term as Competition Commissioner (April 2009), never made it to the formal legislative procedure due to political opposition to some of its provisions. The unofficial Directive proposal contained some rules on collective claims (articles 4-6) and also included limited reference to the coordination of damages claims and public enforcement proceedings (article 8).

During this initial period, the discussion focused on the compensatory goals of damages claims, and it even led to the adoption of some guidance on the quantification of damages for judges ${ }^{9}$.

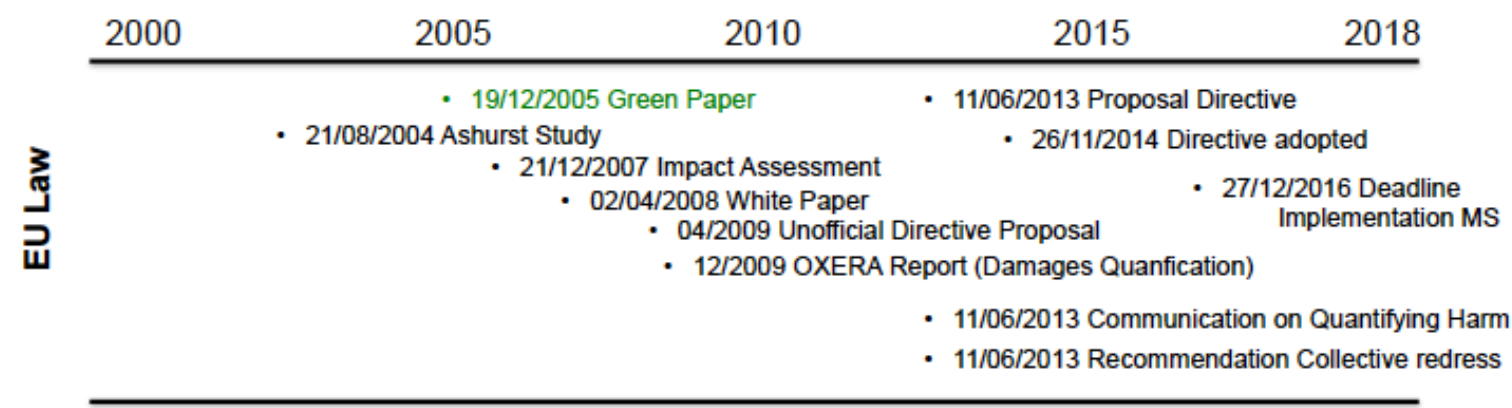

- 20/09/2001 Courage (C- 453/99)

- $1307 / 2006$ Manfredi (C-295/04 to 298/04)

$06 / 06 / 2011$ Donau Chemie (C-536/11)
․ 14/06/2011 Pfleiderer (C-360/09)
$\cdot 27 / 02 / 2012$ EnBW Energie (C-365/12P)
$\cdot 06 / 122012$ Otis (C-199/11)
$\cdot 05 / 06 / 2014$ Kone (C-557/12)

In 2010, with Commissioner Joaquin Almunia (2000-2004) at the helm, the Commission resumed the drive towards the adoption of EU rules on antitrust damages claims. Apparently, collective claims had been considered as the "Achilles heel” in the earlier proposal by the Commission, and for that reason

\footnotetext{
${ }^{7}$ White Paper on Damages actions for breach of EC antitrust rules, COM(2008) 165 final and Staff Working paper accompanying the White Paper on Damages actions for breach of EC antitrust rules, COM (2008) 165 final, 2 of April 2008 (hereinafter “Staff Working paper 2008”).

${ }^{8}$ Consolidated version of the Treaty on the Functioning of the European Union (OJ C 326 of 26/10/2012).

${ }^{9}$ European Commission, Quantifying antitrust damages. Towards non-binding guidance for courts (study prepared by OXERA and a multi-jurisdictional team of lawyers lead by Assimakis Komninos, with economics assistance of Dr. Walter Beckert, Professor Eric Van Damme, Professor Mathias Dewatripoint, Professor Julian Franks, Dr Adriaan ten Kate and Professor Patrick Legros), December 2009.
} 
this was left out of the discussion, reappearing in diluted form in a broader discussion concerning collective redress mechanisms in case of violations of any right granted under EU law ${ }^{10}$.

Moreover, the need to establish clearer rules on the coordination of public and private enforcement become more urgent after the EUCJ gave its rulings in Pfleiderer (2011) ${ }^{11}$, Donau Chemie (2012) ${ }^{12}$ and EnBw (2014) ${ }^{13}$. In the meantime, the EUCJ also provided significant rulings in Otis (2012) ${ }^{14}$ and Köne (2014) ${ }^{15}$, which further consolidated the EU case-law on antitrust claims. Finally, Directive 2014/104/EU was adopted at the end of Almunia's term as Commissioner, with substantial changes from the text of the 2009 unofficial proposal ${ }^{16}$.

With the adoption of the Directive, the EU has advanced from the process of negative harmonization through the case law of the EUCJ ${ }^{17}$, which supported the right of compensation of victims of anticompetitive infringements as a recognition of the principle of effectiveness of the EU law competition prohibitions. Indeed, the Directive expressly endorses the principles of effectiveness as the tool that -together with the principle of equivalence- should guide Member States (hereinafter MS) in implementing the Directive (article 4). Although this is a mandate that MS should take into account in the transposition of the Directive, it may also have relevance for the national courts in deciding damages claims, especially given the open and vague nature of some of its rules ${ }^{18}$. Additionally, when the national

\footnotetext{
${ }^{10}$ European Commission, Staff Working Document, Public Consultation: Towards a Coherent Approach to Collective redress, SEC (2011) 0173, 4 of February 2011 and Commission Recommendation of 11 of June 2013 on common principles for injunctive and compensatory collective redress mechanisms in the MS concerning violations of rights granted under EU Law (OJ L 201 of 26 of July 2013).
}
11 Judgment of 14 of June 2011(Grand Chamber) C-360/09 Pfleiderer AG v. Bundeskartellamt (ECLI:EU:C:2011:389).

12 Judgment of 6 of June 2013 (First Chamber) C-536/11 Bundeswettbewerbsbehörde v. Donau Chemie et al. (ECLI:EU:C:2013:366).

${ }^{13}$ Judgment of 27 of February 2014 (Third Chamber) C-365/12P Commission v. EnBW Energie BadenWürttemberg et al. (ECLI:EU:C:2014:112). ${ }^{14}$ Judgment of 6 of November 2012 (Grand Chamber) C-199/11 Europese Gemeenschap v Otis NV \& others
(ECLI:EU:C:2012:684).

${ }^{15}$ Judgment of 5 of June 2014 (Fifth Chamber) C-557/12 Kone AG and Others v ÖBB-Infrastruktur AG, (ECLI:EU:C:2014:1317).

${ }^{16}$ OJ L 349 of 5 of December 2014.

${ }^{17}$ See Lorenzo Pace “The Court of Justice 'Antitrust Enforcement Negative Harmonisation Framework' and the

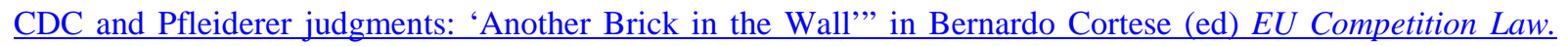
Between Public and Private Enforcement, 241-255 and See also Rainer Kulms "Competition Law Enforcement under informational Asymmetry” China-EU Law Journal 5: 258. In reality, however, several positive obligations may be extracted from the case-law of the ECJ, see Pieter Van Cleynenbreugel "Embedding Procedural Autonomy: The Directive and National Procedural Rules” in Maria Bersgtröm, Marios Iacovides \& Magnus Strand (eds.) Harmonising EU Competition Litigation, The EU Directive and beyond, Hart 2016, 103.

${ }^{18}$ The Directive contains specific obligations for national courts but in furtherance of the principle of procedural autonomy, many issues are not dealt with in it or the transposition measures, further empowering national courts, 
rules adopted in implementing the Directive leave room for judicial discretion, the national court's duty to act in the way most conducive to the effective enforcement of EU law (article 4.3 of the Treaty of the European Union/TEU ${ }^{19}$ ) should drive their judicial decision-making, pre-empting otherwise relevant national procedures or rules ${ }^{20}$.

\section{The Goals of the Directive.}

The Directive is aimed at providing rules for effective compensation of victims of antitrust infringements, harmonizing some rules concerning damages claims, so that there can be a single and common level-playing field for these claims across the $\mathrm{EU}^{21}$.

Minimum harmonization is sought by introducing limited rules on relevant issues concerning victims' claims for damages in case of antitrust infringements. The Directive focuses solely on damages claims aimed at allowing victims to be compensated for losses incurred in terms of overcharges (that the Commission estimates to range from $0,20 \%$ to $0,60 \%$ of the GDP of the EU, for cartels alone) ${ }^{22}$, in addition to providing an additional deterrent factor of the competition prohibitions in the TFEU ${ }^{23}$.

The Directive also aims at ensuring coordination of private claims and public enforcement ${ }^{24}$. In this context, is mainly concerned with protecting the investigations of the European Commission and of the National Competition Authorities (hereinafter NCAs), by limiting access or disclosure of information included in their administrative files. In this regard, rules are introduced to prevent any

see Katryn Wright “The Ambit of Judicial Competence after the EU Antitrust Damages Directive” (2016) Legal Issues of Economic Integration 43/1: 15-40.

${ }^{19}$ Consolidated version of the Treaty on European Union (OJ C 326 of 26 of October 2012).

${ }^{20}$ See Anna Wallerman "Towards an EU Law Doctrine on the Exercise of Discretion in National Courts? The Member States' Self Imposed Limits on National Procedural Autonomy” (2016) Common Market Law Review 53: 359 ("Discretionary rules thereby sometimes -although not consistently- function as a back door, though which EU law can enter national procedural systems unhindered by national legal requirements that would otherwise, legitimately, bar it at the front gate"). See also Katri Havu "EU Law in Member State Courts: 'Adequate Judicial Protection’ and Effective Application: Ambiguities and Non-sequiturs in Guidance by the Court of Justice?” (2016) Contemporary Readings in Law and Social Justice 8/1:158-187.

${ }^{21}$ Article 1.1. See also recitals 7, 8 and 14 (pointing to the diversity of approaches and rules in different MS)

${ }^{22}$ Ranging from $€ 25$ to $€ 69$ billion per year, according to 965 of European’s Commission’s Staff Working Document. Impact Assessment Report: Damages actions for breach of the EU antitrust rules accompanying the proposal of Directive, SWD(2013) 203 final, 11 of June 2013.

${ }^{23}$ See Paolissa Nebbia "Damages Actions for the Infringement of EC Competition Law: Compensation or Deterrence" (2008) European Law Review 33/1: 23-43. Although the initial focus on the deterrent force of damages claims in the Green and White papers (see Staff Working Paper 2005 9ศ5,6 \& 12 and Staff Working Paper2008 \$ף15 and 17) has been dropped from the Directive by the prohibition on overcompensation and punitive damages (article 3.3), nevertheless damages paid in compensation may still be considered as an additional "fine" imposed on the infringer.

${ }^{24}$ Article 1.2. 
damage claims brought before national courts from interfering with, or distorting, infringement proceedings and decisions taken by the European Commission and the NCAs.

In combining these two contradictory goals, the Directive gives preference to public enforcement over the promotion of private claims for damages ${ }^{25}$, adopting a distinctive approach to that set out in the earlier EUCJ case-law ${ }^{26}$. In its attempt to promote compensation, some of its rules are fraught with vague mandates or complexities that may hinder and impede rather than ease victims' claims. That's the case, for example, of damages claims in which there might have been some kind of passing-on (see infra §3.3.5) or claims where there one of the defendants had settled before litigation (see infra §3.3.6). On the other hand, the provision aimed at protecting immunity beneficiaries facing a liability claim in cartel follow-up claims is complex to enforce and it may lead to unpredictable and undesirable outcomes (see infra $\$ 3.3 .4)^{27}$.

\section{The Directive: legal grounds and rules.}

In analysing the Directive, we will consider its legal basis under EU Law (infra §3.1), and briefly describe its provisions (see infra §3.3). It cannot be denied that certain Directive rules will produce some impact on the successful pursuit of damages claims by victims of competition infringements, but it is necessary to reflect on the more subtle and underlying features of the Directive that may explain why and how that impact may not be the one envisaged or intended by its drafters.

\subsection{Why a Directive? Legal basis.}

To date, Regulations have been the only rules adopted on the basis of article 103 of the TFEU. However, a Directive was the preferred option in this case. The change in legal basis and type of EU law adopted was based, in part, with the compensatory goal mentioned above and with the content of the rules adopted: affecting substantive tort and civil procedural issues governed by MS national laws, most of which will be strongly and deeply rooted in their domestic legal traditions. For those reasons,

\footnotetext{
${ }^{25}$ See Caterina Migani "Directive 2014/104/EU: In Search of a Balance between the Protection of Leniency Corporate Statements and an Effective Private Competition Law Enforcement” (2014) Global Antitrust Review 81-111.

${ }^{26}$ See Sebastian Peyer "Compensation and the Damages Directive” (2016) European competition Journal 12/1: 24-26 and "The Antitrust Damages Directive -much ado about nothing?” in Mel Marquis \& Roberto Cisotta (ed.) Litigation and Arbitration in EU Law, Elgar 2016, 36 and 45-46.

${ }^{27}$ In this regard, see the proposal by Christian Kersting "Removing the Tension Between Public and Private Enforcement: Disclosure and Privileges for Successful Leniency Applicants” (2014) Journal of European Competition Law \& Practice 5/1: 2-5 (civil immunity for all leniency beneficiaries which would make unnecessary the specific disclosure regime infra §3.3.8). See also Miriam C. Buiten, Peter Van Wijck \& Jan Kees Winters "Does the European Damages Directive Make Consumers Better Off?” (2018) Journal of Competition Law \& Economics 14/1:91-104.
} 
the use of a Directive was preferred ${ }^{28}$. The Directive is based on articles 103 and 114 of the TFEU ${ }^{29}$, aimed at achieving some harmonization of national rules while respecting the institutional and procedural autonomy of MS.

In addition, the Antitrust Damages Directive marks the very first time the European Parliament has been engaged in adopting legislation on the enforcement of articles 101 and 102 of the TFEU.

Indeed, given the uneven level of protection that exists for victims' right to compensation in different MS, the Commission used article 114 of the TFEU as a complementary legal basis for the Directive. The Directive harmonizes some civil procedure and tort rules to further ensure the proper functioning of the internal market. In doing so, in practice, the Directive encroaches upon MS' powers in matters that, in the past, have been alien to the competence of the EU. Although the diverse remedial and procedural rules of MS set the legal framework in which antitrust damage claims may be brought, the Directive introduces several rules that make important inroads eroding and limiting national remedial autonomy (see infra §3.2).

\subsection{Eroding and Encroaching Upon National Remedial Autonomy.}

The direct applicability of articles 101 and 102 of TFEU by national courts had been recognized by the EUCJ for many years ${ }^{30}$, and was given express legal ratification in Regulation 1/2003 (article $6)^{31}$. However, EU law has largely been respectful of the autonomy of MS in providing the institutional and operative settings for that application to take place $^{32}$.

\footnotetext{
${ }^{28}$ Indeed, given the rigidity and the little margin left by some rules on the coordination of public enforcement and damages claims (see infra §3.3.8), it could well be argued that, for some of its provisions, a Regulation would be a more suitable instrument. However the Commission finally opted for a Directive in order to provide room for national specificities that could not be respected otherwise. A similar reasoning explains the Proposal for $a$ Directive to empower the competition authorities of the Member States to be more effective enforcers and to ensure the proper functioning of the internal market, 22 of March 2017.
}

${ }^{29}$ The 2009 unofficial draft was based only on article 103, and it excluded the participation of the European Parliament.

${ }^{30}$ See Judgment of the Court of 27 of March 1974, Belgische Radio en Televisie v SV SABAM and NV Fonior, 127-73 (ECLI:EU:C:1974:25). In the context of arbitration proceedings see Judgment of the Court of 1 of June 1999, Eco Swiss China Time Ltd v. Benetton International NV, C-126/97 (ECLI:EU:C:1999:269).

${ }^{31}$ See 99 of Commission Notice on the cooperation between the Commission and courts of the EU Member States in the application of Articles 81 and 82 (OJ C101 of 27 of April 2004).

${ }^{32}$ Of course, there were some restrictions, the most obvious of which is article 16.1 of Regulation $1 / 2003$, that binds national courts to EC decisions declaring an infringement of articles 101/102 TFEU, a major limitation on the institutional autonomy of MS (interpreted by some authors as going against constitutional principles of many MS). For an overview see Asimakkis P Komminos "Effect of Commission Decisions on Private Antitrust Litigation: Setting the Story Straight” (2007) Common Market Law Review 44: 1387-1428. 
Therefore, in the system of multi-level enforcement of EU Competition Law, MS have been free to set the institutional framework and procedures for application of the law, as long as the effectiveness of EU law rights is guaranteed and that the rules and processes are not less favourable for victims than those governing similar actions resulting from infringements of national law ${ }^{33}$.

In order to enhance and promote damages claims, the Antitrust Damages Directive introduces EU rules that erode the autonomy of MS to set their own rules and procedures. A right to damages based on EU law is recognized and thereto the civil liability of infringers is established, and some conditions and requirements governing claims are set. The provisions of the Directive, together with the principle of effectiveness, embody the victims' right to seek compensation for the harm caused by competition law infringements as a way to place them in the position they would had been but for the infringement, ruling contrary to EU law any national rule that makes those claims excessively difficult or impossible. In other words, divergences in the settings provided by MS for the enforcement of the right to compensation will exist, and such diversity is not problematic as long as it does not turn into ineffectiveness of such right.

In that manner, the principle of national institutional and procedural autonomy is encroached upon, limiting the leeway and discretion that MS and their courts may have in exercising their powers. In addition, the principles of effectiveness and equivalence, together with the principle of sincere cooperation, implies a duty to act in the way most conducive to the effective enforcement of EU law (article 4.3 of TEU) that will inevitably constrain the power or discretion of national courts in conducting national proceedings and in interpreting national law ${ }^{34}$.

On one hand, the Directive contributes another limb in the growing body of EU tort rules (like the rules on State liability, IP enforcement, Unfair Competition and Product liability) ${ }^{35}$. On the other hand,

${ }^{33}$ See 95 of judgment of 16 of December 1976, case 33/76, Rewe-Zentralfinanz eG and Rewe-Zentral AG $v$ Landwirtschaftskammer für das Saarland (ECLI: EU:C:1976:188); $₫ 12$ of judgment of 16 of December 1976, case 45/76, Comet BV v Produktschap voor Siergewassen (ECLI:EU:C:1976:191); $\uparrow \uparrow 18$ \&23 of judgment of 10 of April 1984, 79/83, Dorit Harz v. Deutsche Tradax GmbH (ECLI:EU:C:1984:155); $\{44$ of judgment of 7 of July 1981, 158/80 Rewe-Handelsgesellschaft Nord $\mathrm{mbH}$ and Rewe-Markt Steffen v. Hauptzollamt Kiel (ECLI:EU:C:1981:163); $\uparrow 12$ of judgment of 9 of November 1983, C.-199/82 Amministrazione delle Finanze dello Stato v. SpA San Giorgio (ECLI:EU:C:1983:318) and $\uparrow \uparrow 36$ and 37 of judgment of 15 of September of 1998, C231/96, Edis v. Ministero delle Finanze (ECLI:EU:C:1998:401). See also $110(\mathrm{c})$ Commission Notice on the cooperation between the Commission and courts of the EU MS.

${ }^{34}$ On this movement from discretion to obligation/duty in interpreting national rules adopted in implementation of Directives see $\uparrow \uparrow 111-113$ of EUCJ judgment (Gran Chamber) of 5 of October 2004, Bernhard Pfeiffer (C-397/01), Wilhelm Roith (C-398/01), Albert Süß (C-399/01), Michael Winter (C-400/01), Klaus Nestvogel (C-401/01), Roswitha Zeller (C-402/01) and Matthias Döbele (C-403/01) v. Deutsches Rotes Kreuz, Kreisverband Waldshut eV., C-398 /01 to C-403/01, IEU:C:2004:584 and Wallerman (2016) Common Market Law Review 53: 339-360.

${ }^{35}$ See Ulf Bernitz “Introduction to the Directive on Competition Damages Actions” in Bersgtröm, Iacovides \& Strand (eds.) Harmonising EU Competition Litigation, 4; Niamh Dunne "Antitrust and the Making of European Tort Law” Oxford Journal of Legal Studies 2015: 1-34; Okeoghene Odudu \& Albert Sánchez Graells "The interface of EU and national tort law” in Paula Giliker (ed.) Research Handbook on European Tort Law, Elgar 2017, 154-183. and Francisco Marcos \& Albert Sánchez Graells “Towards a European Tort Law-Damages Actions 
the Directive seeks to empower private claimants to enforce the EU competition rules through the national courts (private enforcement) ${ }^{36}$. In this way, the Directive builds upon the right to effective legal protection [article 19(1) TEU and article 47 of Charter of Fundamental Rights of the EU ${ }^{37}$ ]. Finally, although procedural law belongs largely within the domain of MS' autonomy, some of the rules of the Directive further extend the growing body of EU procedural rules that, together with the principles of effectiveness and equivalence, may further constrain national rules and proceedings ${ }^{38}$.

\subsection{Content of the Directive.}

The Directive does not introduce a comprehensive set of rules for antitrust damages claims or regarding the interaction of damages claims and public enforcement investigations, but it contains only a few substantive and procedural initiatives "cherry-picked" from the national regimes in the EU that have shown in the past to be more proactive and successful in encouraging antitrust damages claims (Germany, UK \& the Netherlands) ${ }^{39}$.

A large part of the Directive codifies and elaborates on the issues highlighted in six judgments of the ECJ on these matters (Table 1).

\section{Table 1}

\begin{tabular}{|l|l|l|}
\hline ECJ Judgment & Case reference & ECLI \\
\hline Judgment of 20/09/2001 (Grand Chamber) & C453/99 Courage & EU:C:2001:465 \\
\hline Judgment of 13/07/2006 (Third Chamber) & $\begin{array}{l}\text { C-295/04 to C-298/04 } \\
\text { Manfredi }\end{array}$ & EU:C:2006:461 \\
\hline Judgment of 14/06/2011(Grand Chamber) & C-360/09 Pfleiderer & EU:C:2011:389). \\
\hline Judgment of 06/11/2012 (Grand Chamber) & C-199/01 Otis & EU:C:2012:684 \\
\hline Judgment of 27/02/2014 (Third Chamber) & C-365/12P EnBW Energie & $\underline{\text { EU:C:2014:112 }}$ \\
\hline
\end{tabular}

for Breach of the EC Antitrust Rules: Harmonizing Tort Law through the Back Door” (2008) European Review of Private Law 3: 481-485.

${ }^{36}$ See Folkert G Willman Private Enforcement of EU Law before National Courts. The EU legislative framework, Elgar 2015 and "The end of absence: the growing body of EU legislation on private enforcement and the main remedies it provides for” (2016) Common Market Law Review 53: 887-936, 2016.

${ }^{37}$ OJ C 326 of 26 of October 2012.

${ }^{38}$ See Andrea Biondi \& Ravi S. Mehta "EU Procedural Law" in Dennis Patterson \& Anna Sodersten (eds.) The Companion to EU and International Law Wiley 2016, 155-166 (affecting purely domestic procedures, and beyond the traditional focus on cross-country or transnational aspects).

${ }^{39}$ See Anneli Howard “Too little, too late? The European Commission’s Legislative Proposals on Anti-Trust Damage Actions” (2014) Journal of European Competition Law \& Practice 4/6: 456. See Anthony Maton, Vijaiya Poopalasingam, Marc Kuijper \&Timo Angerbauer "The Effectiveness of National Fora in Europe for the Practice of Antitrust Litigation” (2011) Journal of European Competition Law \& Practice 2/5: 489-508. 
Following the two goals of the Directive (compensation and relationship of damages claims with public enforcement proceedings), its rules deal both with various features of antitrust damages claims and with some aspects of the interaction of claims with public enforcement in case of follow-on claims (Table 2).

Table 2

\begin{tabular}{|l|l|l|}
\hline ISSUES & ARTICLES & RECITALS \\
\hline OPERATIVE PART OF DIRECTIVE & 2 & \\
\hline Definitions & 2 & $\mathbf{5 3 - 5 5}$ \\
\hline Addresses; Transposition, Review \& Entry into force & $20-21$ \& 23-24 & $\mathbf{5 6}$ \\
\hline Temporal Application & 22 & $3,4,5,11-13$ \\
\hline DAMAGES CLAIMS & 1.1 and 3 & 36 and 49 \\
\hline Compensatory principle & 10 & $45-47$ \\
\hline Limitation periods & 17 & $37-38$ \\
\hline Quantification of harm & 11 & $39-44$ \\
\hline Multi-party responsibility & $12-15$ & $48-52$ \\
\hline Passing-on of Harm/ Indirect purchasers & $18-19$ & $14-19$ \\
\hline Consensual Dispute Resolution & 6 and 8 & \\
\hline Disclosure & 9 & $34-35$ \\
\hline INTERACTION WITH PUBLIC ENFORCEMENT & 9 & $20-33$ \\
\hline Binding NCA Decisions & 7 & \\
\hline Access to the file &
\end{tabular}

\subsubsection{Compensatory principle: Harm caused by infringement.}

The Directive enunciates a right in damages for harm caused by infringement of EU competition prohibitions: victims are enabled to claim compensation. Achieving 'full compensation' is the main declared aim of the Directive, repeated in several of its recitals and rules ${ }^{40}$. Following the case law of the EUCJ ${ }^{41}$, the Directive aims at ensuring full compensation, excluding overcompensation (article 3.3).

\footnotetext{
${ }^{40}$ Articles 1.1 ("anyone who has suffered harm caused by an infringement of competition law by an undertaking or by an association of undertakings can effectively exercise the right to claim full compensation for that harm from that undertaking or association") and 3.1 ("any natural or legal person who has suffered harm caused by an infringement of competition law is able to claim and to obtain full compensation for that harm").

${ }^{41}$ See also $\$ 10$ (b) of Commission Notice on the cooperation between the Commission and courts of the EU Member States in the application of Articles 81 and 82 (Official Journal C101 of 27/04/2004). However, it is important to remember that before, in its judgment of 13 April 1994, C-128/92 Banks v. British Coal (ECLI:EU:C:1994:130) the EUCJ had rejected compensation( $(1921$ \& 22), contrary to the Opinion of AG Van Gerven of 27 of October 1993, ECLI:EU:C:1993:860 (\$ף44 \& 45).
} 
Full compensation includes both compensation for actual loss (damnum emergens) and for loss of profit (lucrum cessans), plus the payment of interest ${ }^{42}$. It "shall place a person who has suffered harm in the position in which that person would had been the infringement of competition law not been committed" (article 3.2).

Compensation claims will need to prove and to quantify the harm produced by an infringement of competition law and the causal link between the infringement and the harm ${ }^{43}$. Nonetheless, the Directive is silent regarding the standard of proof, fault and causation requirements ${ }^{44}$. Those conditions will be governed by national rules in force in each MS. However, if the national law standards impede or make it excessively difficult for claims to be pleaded and to succeed, this will be contrary to the principle of effectiveness and the general duty of courts not to infringe general principles of EU Law ${ }^{45}$.

In stand-alone claims the claimant has the burden of the proving the infringement ${ }^{46}$; if the suit follows a prior infringement decision adopted by the European Commission or a NCA, claimants benefit from that infringement decision (see article 16.1 of Regulation 1/2003 and infra §3.3.9).

Moreover, the compensatory principle is further enhanced by the rebuttable presumption of harm in cartel cases. Defendants can reverse the presumption if they provide evidence of an absence of harm (infra §3.3.3).

\subsubsection{Limitation periods.}

The right to compensation for harm caused by antitrust infringements is dependent on the bringing of a claim against the infringers in due time. Before the Directive, there were a variety of limitation periods for damages claims across the different MS. The Directive lays down clear rules concerning both the duration and running of the limitation period.

The limitation period should last at least five years (article 10.3), and it shall never begin running before the infringement has ceased and the claimant knows, or can reasonably be expected to know, that

\footnotetext{
42 995 of judgment of 13 of July 2006 Manfredi C-295/04 to C-298/94 (EU:C:2006:461). How interest is to be calculated is only dealt with in recital 12 . The amount of interest can be substantial in case of long-running infringements and if the damages claim is filed following an infringement decision by a competition authority.

${ }^{43}$ See $₫ 61$ of judgment of 13 of July 2006 Manfredi C-295/04 to C-298/94 (EU:C:2006:461). See also $₫$ |33 in fine of Judgment (Third Chamber) of 18 of January 2007 City Motors Groep NV v. Citroën Belux NV, C-421/05 (ECLI:EU:C:2007:38).

${ }^{44}$ See Magnus Strand "Labours of Harmony: unresolved issues in competition damages" (2017) European Competition Law Review 38: 204 (in the article he analyses the issues of fault, causation and interest payment): "Directive 2014/104 leaves most of the core issues of tort and damages law, as briefly outlined here, unharmonized"). See also Vlatka Butorac Malnar "The Kone Case: A Missed Opportunity to Put the Standard of Causation Under the Umbrella of the EU” in Vesna Tomljenović, Nada Bodiroga-Vukobrat, Vlatka Butorac Malnar, Ivana Kunda (eds.) EU Competition and State Aid Rules: Public and Private Enforcement, Springer 2017, 175-195.

${ }^{45}$ Rainer Kulms “Competition Law Enforcement under informational Asymmetry” China-EU Law Journal 5: 226.

${ }^{46}$ See article 2 of Regulation 1/2003 (Burden of Proof).
} 
the conduct constituted an infringement, that it caused harm to the claimant and the identity of the infringers (article 10.2). In order to coordinate damages claims with potential enforcement proceedings before the European Commission or NCAs, it is further established that the period shall be suspended or interrupted until at least one year after an infringement decision is final or the public enforcement proceedings were otherwise terminated (article 10.4). Finally, special rules are included concerning the running of the limitation period if consensual dispute resolution is sought by the parties (article 18.1).

\subsubsection{Quantification of Harm.}

One of the main difficulties faced by parties injured by infringements of competition law is the quantification of the harm suffered. The Antitrust Directive introduces some rules in this regard. Those rules qualify the domestic rules on quantification of harm in damages claims in force in each MS. Moreover, a Communication on Quantifying harm in antitrust damages actions, ${ }^{47}$ accompanied by a Practical Guide, ${ }^{48}$ were adopted by the Commission when the Directive Proposal was presented, and they outline the diverse methods and techniques available to quantify harm.

In many cases, claimants will base their claims on an expert economic report that determines the quantum of the harm caused by the antitrust infringement, including any price and quantity effects and any mitigating circumstances (also passing-on) ${ }^{49}$.

Aside from the rules easing access to evidence, which may help claimants in substantiating their claim (see infra §3.3.7), the Directive requires that "neither the burden nor the standard of proof required for the quantification of harm renders the exercise of the right to damages practically impossible or excessively difficult" (article 17.1). Additionally, MS are required to empower courts with sufficient discretion to estimate the harm ex aequo et bono themselves, "if it is established that the claimant suffered harm but it is practically impossible or excessive difficult to precisely to quantify the harm suffered on the basis of the evidence available"50. MS also need to ensure that NCAs may, if requested by the courts, and as long as NCAs consider it appropriate, assist them in quantifying harm $(\text { article 17.3) })^{51}$.

\footnotetext{
${ }^{47}$ OJ 167 of 13 of June 2013.
}

${ }^{48}$ Commission Staff Working Document Practical Guide Quantifying Harm in Actions for damages based on breaches of Article 101 or 102 of the TFEU, SWD(2013) 205, 1 of June 2013

${ }^{49}$ See Emily Clark \& Ruth Sander “Navigating the Quantum Minefield in Cartel Damage Cases” (2015) Journal of European Competition Law \& Practice 6/3:158 and 162-167.

${ }^{50}$ See Odudu \& Sánchez Graells in Giliker (ed.) Research Handbook on European Tort Law, 165-166.

${ }^{51}$ This establishes as a requirement what it is only contemplated as a possibility in article 15.4 of Regulation 1/2003. For a survey of the solutions available in different MS see Bernardo Cortese "Defining the Role of Courts and Administrative Bodies in Private Enforcement in Europe: United in Diversity?" in Cortese (ed) EU Competition Law. Between Public and Private Enforcement, Wolters 2014, 145-172. As it is known, a similar power is bestowed upon the Commission in article 15.1 of Regulation 1/2003. 
On the other hand, in the particular case of cartel infringements, the Directive seeks to alleviate the burden of proof for claimants by the introduction of a rebuttable presumption of harm (article 17.2). The Directive is focused on overcharges resulting from cartels, and to help them overcome the difficulties that claimants may face in obtaining evidence to prove such ${ }^{52}$. Nevertheless, infringers can rebut this presumption, and claimants still need to prove causality and estimate the amount of harm suffered $^{53}$. The benefit of the presumption will probably negligible if it were not coupled with the national courts' power to estimate the harm and the NCAs possibility to assist therewith ${ }^{54}$.

\subsubsection{Multi-party responsibility.}

If several parties have committed an antitrust infringement, the Directive establishes the joint and several liability of all co-infringers. This further enhances the victims' right to full compensation as they can require compensation from any of the infringing parties (article 11).

An exception is introduced to this rule to protect the immunity beneficiary, who will only be liable to "its direct or indirect purchasers or providers" and to the rest of the victims "only where full compensation cannot be obtained from the other undertakings that were involved in the same infringement" (article 11.4) ${ }^{55}$. In addition, the immunity beneficiary shall be liable to "umbrella" claimants in the proportion of its relative responsibility for that harm (article 11.6) ${ }^{56}$.

An additional exception to the co-infringers' joint and several liability was introduced by the European Parliament to protect infringers which are Small and Medium Enterprises (SMEs) ${ }^{57}$, who will only be liable to their direct and indirect purchasers, as long as their market share in the relevant market was below 5\% at any time during the infringement, and when the application of the rule of joint and several liability would irretrievably jeopardise their economic viability and cause their assets to lose all

\footnotetext{
52 This will more likely occur in follow-on claims, see Marios C. Iacovides "The Presumption and Quantification of Harm in the Directive and the Practical Guide” in Bersgtröm, Iacovides \& Strand (eds) Harmonising EU Competition Litigation, 295.

${ }^{53}$ Recital 47.

${ }^{54}$ See Iacovides in Bersgtröm, Iacovides \& Strand (eds) Harmonising EU Competition Litigation, 296 and 312313.

55 The Directive does not clarify what the phrase "full compensation cannot be obtained" from the other coinfringers means, see Niamh Dunne "Courage and compromise: the Directive on Antitrust Damages" (2015) European Law Review 40/4: 595 and Truli "Will Its Provisions Serve Its Goals? Directive 2014/104/EU on Certain Rules Governing Actions for Damages for Competition Law Infringements” (2016) Journal of European Competition Law \& Practice 7/5: 307-308.
}

${ }^{56}$ Recital 38, which was added by the European Parliament as a way of removing part of the privilege that the Commission provided the immunity beneficiary in the Proposal, see Andreas Schwab "Finding the Right Balancethe Deliberations of the European Parliament on the Draft Legislation Regarding Damage Claims” (2014) Journal of European Competition Law \& Practice 5/2:66.

${ }^{57}$ See Commission Recommendation 2003/361/EC of 6 May 2003 concerning the definition of micro, small and medium-sized enterprises (OJ L126 of 20/05/2003). 
their value (article 11.2) ${ }^{58}$. In practice, it seems likely that gathering all the information required for the exception to apply will prove an un-surmountable task for both potential claimants and defendants ${ }^{59}$.

Finally, a general contribution principle among all co-infringers is also established by the Directive. As an internal liability rule among co-infringers, any co-infringer has "the right to obtain $a$ contribution from other co-infringers if it has paid more compensation than its share" (article 11.5). National applicable law should determine what is the share of liability corresponding to each of them ${ }^{60}$.

\subsubsection{Damages spread along a distribution chain.}

The Directive extends the right to compensation to "any natural or legal person who has suffered harm caused by an infringement of competition law", regardless of their position in the supply or distribution chain. That includes victims which were in a direct relationship with the infringer, but also indirect victims, be they purchasers or suppliers (article 12). In drafting the rules concerning compensation of indirect victims of the infringement, MS must avoid overcompensation or infringer's absolution of liability. These claims will more likely will follow-on a previous infringement decision by the European Commission or of a NCA that will make indirect victims aware of the infringement and ensuing harm they have suffered ${ }^{61}$. However when consumers are the indirect victims of the competition infringement, the likelihood of their claims depends on the availability of adequate collective redress mechanisms ${ }^{62}$.

In introducing compensation for indirect victims of the infringer, the Directive refers to the overcharge harm passed-on to them. The passing-on of the overcharge can operate as a defence invoked by the infringing party (article 13) or offensively, raised by indirect purchasers (article 14) ${ }^{63}$.

58 This exception would not be applicable where the SME was the one that led the infringement or had coerced other undertakings to participate therein or the SME had previously been found to infringe competition law (article 11.3).

${ }^{59}$ See Odudu \& Sánchez Graells in Giliker (ed.) Research Handbook on European Tort Law, 172-173; Peyer in Marquis \& Cisotta (ed.) Litigation and Arbitration in EU Law, 41 and (2016) European Competition Journal 12: 104-105.

${ }^{60}$ Recital 37 refers to national law but their respective turnovers, market shares and role in the infringement are relevant criteria that might be taken into account.

${ }^{61}$ See Elizabeth Eklund "Indirect Purchasers- Is there anything new in the Directive? An Introductory Overview of the Current and Future Status of Indirect Purchaser in the EU” in Berstrong, Iacovides \& Strand (eds) Harmonising EU Competition Litigation, 272.

${ }^{62}$ See Dunne (2015) European Law Review 40/4: 588 and 598; Žygimantas Juška “The Effectiveness of Antitrust Collective Litigation in the European Union: A Study of the Principle of Full Compensation” (2017) International Review of Intellectual Property \& Competition Law 49/1: 81-81 and, extensively, Maria Ioannidou Consumer involvement in Private EU Competition Law Enforcement, Oxford University Press 2015, 182-200.

${ }^{63}$ Nevertheless, as the passing-on refers merely to the overcharge, there will probably be part of the harm that remains with direct victims and therefore "where the passing-on resulted in reduced sales and thus harm in the 
To strengthen the standing of indirect purchasers and to facilitate their claims, a rebuttable presumption of passing-on comes into play if the indirect purchaser shows that the defendant committed an infringement of competition law, that the infringement resulted in an overcharge for the direct purchaser of the defendant, and that the indirect purchaser bought the goods or services object of the infringement, or other goods or services derived from, or containing, them (article 14.2) ${ }^{64}$.

As indicated before, this presumption will not preclude claims by direct victims, and their share of damages with indirect victims will depend on the degree of passing on of the overcharge, which each of them will have to quantify.

The panoply of rules aimed at facilitating compensation claims by indirect victims is complemented by a rule to prevent multiple or absence of liability of infringers due to potential claims by different injured parties (article 15) ${ }^{65}$. The Commission is required to issue guidelines on how to estimate the overcharge passed on to indirect purchasers (article 16) ${ }^{66}$.

\subsubsection{Consensual Dispute Resolution.}

The Directive seeks to promote consensual resolution among infringers and victims on the basis that this will enhance successful damages claims by reducing the uncertainty of litigation and by eliminating its costs ${ }^{67}$. For that purpose, it contains two rules to promote consensual dispute resolution, by giving the parties time for the potential negotiation to take place. The rules are aimed at addressing the interplay of potential negotiation between victims and infringers with the follow-on litigation if an amicable agreement is not reached (or not with all of them). A further incentive for consensual settlement was introduced by the European Parliament in article 18.3 of the Directive, by considering voluntary compensation paid to victims of the infringement in the context of a consensual settlement as a mitigating factor in setting the amount of a possible fine ${ }^{68}$.

form of a loss of profit, the right to claim compensation for such loss of profit should remain unaffected" (recital 40).

${ }^{64}$ Likewise, following what is prescribed in article 17.1 in providing national courts the power to estimate harm when it is impossible or excessively difficult to quantify the harm, article 12.5 expressly recognizes this power in relation to harm to indirect purchasers.

${ }^{65}$ To ensure consistency among decisions of courts of different MS and avoid under and over compensation, the Directive relies on article 30 of Regulation (EU) 1215/2012 of 12 of December 2012 on jurisdiction and the recognition and enforcement of judgments in civil and commercial matters (recast)(OJ L351 of 20/12/12) (see recital 44)

${ }^{66}$ See Study on the Passing-on of Overcharges (2016), which will inform the Guidelines to be adopted by the Commission.

67 q247 of Staff Working paper 2008.

${ }^{68}$ See Schwab (2014) Journal of European Competition Law \& Practice 5: 67-68. See also $\$ 18$ of European Competition Authorities (ECA) Working Group on Sanctions, Pecuniary sanctions imposed on undertakings for infringements of antitrust law. Principles for convergence, May 2008. 
Concerning the timing of any ensuing litigation, limitation periods for legal claims should be suspended during the negotiations (article 18.1) and courts may suspend their proceedings for up to two years if the parties enter into a consensual dispute resolution concerning the claim covered by that action for damages (article 18.2).

The other rule deals with consensual dispute resolution in cases of multi-party responsibility when a settlement is not reached with all the co-infringers (see supra §3.3.4). It is a complex rule that does not lead to a predictable outcome and this makes the non-judicial amicable resolution of the claim less attractive ${ }^{69}$.

Firstly, the claim of the settling injured party will be reduced by the share of the harm attributable to the settling co-infringer (article 19.1). Secondly, any litigation regarding the remaining claim of the settling injured party can be directed only against non-settling co-infringers and they shall not be able to recover contribution for the remaining claim from the settling co-infringer (article 19.2). Thirdly, settling co-infringers are not absolved from liability if the non-settling co-infringers are unable to pay damages corresponding to the remaining claim, in that case injured parties may exercise the remaining claim against the settling co-infringer, unless that option was expressly excluded under the terms of the settlement (article 19.3) ${ }^{70}$. Finally, as an application of the contribution rule of article 11.5 in relation to settling co-infringers, in calculating the amount of contribution among them, courts shall take into account the amount of any damages paid pursuant to a prior consensual settlement involving any of the co-infringers (article 19.4) ${ }^{71}$.

\subsubsection{Disclosure of evidence.}

The difficulties faced by antitrust victims in obtaining access to evidence of the infringing conduct and of the harm they have suffered thereby is one of the obstacles that helps to explain the limited number of antitrust damages claims brought up to date in most MS. Complications may be larger in stand-alone actions where claimants need to construct their suit from scratch than in follow-on actions where claimants may use as ground for their claim a prior infringement decision adopted by the European Commission or a NCA ${ }^{72}$.

\footnotetext{
${ }^{69}$ See Jeroen Kortmann \& Rein Wesseling “Two Concerns Regarding the European Draft Directive On Antitrust Damage Actions” (2013) CPI Antitrust Chronicle, Aug. 2013 (1), 7-8

${ }^{70}$ This rule potentially leaves claims open against settling co-infringers, introducing too much uncertainty and thereby settlements less attractive, see Peyer in Marquis \& Cisotta (ed) Litigation and Arbitration in EU Law, 4243 and European Competition Journal 12: 104-105.

${ }^{71}$ On the difficulties and complexities of this rule, see David Ashton \& David Henry, Competition Damages Actions in the EU. Law \& Practice, Elgar 2013, 123-124; Odudu \& Sánchez Graells in Giliker (ed.) Research Handbook on European Tort Law, 171-172 and, extensively, Carsten Koenig "Making contribution work: the liability of privileged and non-privileged injurers in EU competition law" (2018) European Competition Journal 14 (forthcoming).

${ }^{72}$ The difficulties felt in stand-alone actions will also be present in hybrid/mixed claims. A hybrid/mixed claim is one where the cause of action is partly follow-on and partly stand-alone. This may occur because the decision's
} 
For cartels in particular, where evidence of the arrangements may be secret, claimants will often only act after there is a prior infringement decision adopted by the European Commission or the NCAs. An infringement decision by the Commission or a NCA certainly helps claimants not only in being able to identify themselves as victims but also in building the follow-on claim (see infra §3.3.9).

Nevertheless, claimants need to have access to evidence that allows them to prove their claim (harm, quantification, causation, fault) and most of that evidence may be held by the defendants or third parties (e.g., management accounts, invoices, sales databases, business plans, market research reports, electronic datasets, etc.). Likewise, defendants may need to have access to evidence held by claimants or third parties to counter arguments of the claimants regarding the existence of infringement, the harm and its quantification or the causal link.

In order to tackle this information asymmetry ${ }^{73}$, the Damages Directive introduces several rules on disclosure of evidence ${ }^{74}$. This is one of the major novelties of the Directive, perhaps less so for common law MS (UK and Ireland) where provision for discovery already existed ${ }^{75}$, but it is clearly revolutionary in most continental MS which did not provide access in this way. Indeed the resistance of some MS in the discussions that lead to the adoption of the Directive made these rules being significantly narrowed in their scope ${ }^{76}$. Ultimately, according to the rules finally adopted, disclosure of evidence will be decided upon by the national courts, following the principles of necessity and proportionality, and the protection of confidentiality, and the rules on disclosure are restricted in relation to materials included in Commission or NCA files (infra §3.3.8).

The Directive establishes a system of discovery in which disclosure orders are adopted by courts upon the request of claimants or defendants. Any request for disclosure has to be based "on a reasoned justification containing reasonably available facts and evidence sufficient to support the plausibility of its claims for damages" (article 5.1), which has to identify the items of evidence or relevant categories of evidence to be disclosed as precisely and narrowly as possible (article 5.2). The possibility of requesting access to "categories of evidence" broadens the scope of the discovery available before the Directive in most MS. In addition, the same right should be recognized to defendants regarding, any evidence required to counter the claimant's arguments about the infringement, harm caused and

scope is narrower than the scope of the damages action, in what concerns the material scope (alleging other infringements beyond the one identified in the decision), the temporal scope (e.g., alleging the infringement went on for longer than what was identified in the decision), the subjective scope (e.g., also against a legal person who was not named in the decision).

${ }^{73}$ See recital 15.

${ }^{74}$ See Anca D. Chirita “The Disclosure of Evidence under the 'Antitrust Damages’ Directive 2014/104/EU” in Tomljenović, Bodiroga-Vukobrat, Butorac Malnar, Kunda (eds.) EU Competition and State Aid Rules, 147-173.

${ }^{75}$ On the benefits and costs of discovery, in general, see Robert G. Bone "Discovery" in Gerrit De Geest \& Chris W. Sanchirico (ed) Encyclopedia of Law and Economics, Vol. 7 (Tort Law and Economics), Elgar 2007, 188-202. The Directive acknowledges that in some MS the existing claimant-friendly discovery procedures may allow a wider disclosure of evidence and they may continue to exist, although they will have to adequately respect the safeguards set out in the Directive (article 6.8).

${ }^{76}$ See Howard (2014) Journal of European Competition Law \& Practice 4: 459-460 
causation, including evidence about passing-on the harm that may be held in the claimants' possession (in the context of an article 13 defence, see supra $\$ 3.3 .5)^{77}$.

The Directive builds the discovery provision around the principles of necessity and proportionality ${ }^{78}$. Unsupported or unspecified requests of information should not be admitted. The proportionality principle guides the limits of the disclosure order, taking into account the legitimate interests of all parties and third parties concerned (article 5.3). Indeed, those from whom disclosure is sought must be heard before a disclosure order is adopted (article 5.7).

Among the considerations that have to be taken into account by the national court in issuing the disclosure order are: (a) the available facts and evidence supporting the plea which justify the disclosure request; (b) the scope and cost of disclosure; and (c) the protection of confidential information. In particular, the court should consider the interests of third parties who may be subject to the search for information. Moreover, the protection of legal professional privilege should be given full effect (article 5.6).

Although the protection of confidential information and business secrets should always be considered by the court in ordering disclosure, the Directive expressly states that courts should have the power "to order the disclosure of evidence containing confidential information where they consider it relevant to the action for damages" (article 5.4). Access should be granted in those cases, although proper arrangements should be made to protect such information ${ }^{79}$.

The effectiveness of the rules on disclosure of evidence and the powers of national courts in applying them is guaranteed by a regime of penalties that allows national courts to impose penalties on anyone who fails, or refuses, to comply with a disclosure order; who destroys relevant evidence; who fails, or refuses, to comply with the obligations imposed by the national court to protect confidential information; or who breaches the limits for the use of evidence set by the Directive (article 8.1). The Directive requires MS to set the penalties that can imposed by national courts in such a way that they are effective, proportionate and dissuasive, and those rules should include the possibility of drawing adverse inferences from the behaviour of a party to the damages proceedings, "such as presuming the relevant issue to be proven or dismissing claims and defences in whole or in part, and the possibility to order the payment of costs" (article 8.7).

\subsubsection{Protection of public enforcement.}

Although ensuring and promoting the availability of compensation for antitrust victims is the main goal of the Directive, some of its rules try to address the negative effects that damages claims could raise for the functions of public enforcers of the competition prohibitions (the European Commission and

\footnotetext{
${ }^{77}$ See recital 15.

${ }^{78}$ See recital 16.

${ }^{79}$ See recital 18.
} 
NCAs). In doing so, the Directive tackles some of the potential costs, negative effects and conflicting interests raised by private litigation for the system of competition law enforcement as a whole ${ }^{80}$.

Facilitating damages claims is not irreconcilable with protecting the system of public enforcement ${ }^{81}$. Damages claims supplement the deterrent effect of public enforcement with the compensation of victims. It is undeniably true that there may also be a deterrent value in private enforcement $^{82}$, but that is secondary to its corrective justice goal ${ }^{83}$.

Private damages claims complement action by public authorities against anticompetitive violations, and are arguably the only way to directly compensate victims of antitrust harm. Of course, there are costs arising from allowing and encouraging private enforcement, especially in relation to its coordination with public antitrust proceedings, but those costs should not be exaggerated ${ }^{84}$.

Two articles are devoted to damages claims in which access may be sought to the file of a competition authority (articles 6 and 7, recitals 20-33) ${ }^{85}$. The general discovery regime set out in articles 5 and 8 also applies to disclosure orders to public authorities ${ }^{86}$, including competition authorities, but some specific rules are adopted concerning access to their files (article 6.1).

In addition to the assessment of the necessity and proportionality of requests of disclosure of evidence contained in the files of competition authorities [crafted specifically in this regard by article

\footnotetext{
${ }^{80}$ See Daniel L. Rubinfield “An Empirical Perspective on Legal Process: Should Europe Introduce Private Antitrust Enforcement?” in Peter Nobel \& Marin Gets (eds.) New Frontiers in Law and Economics, Schulthes 2006, 141-149.
}

${ }^{81}$ As suggested by Roger Van den Bergh \& Sonja Keske "Private Enforcement of European Competition Law: Quo Vadis?” (2008) European Review of Contract Law 3: 470-471. They are accurate in pointing that the specific design of rules regarding private claims (amount of damages, collective claims and passing-on defence) will depend on the extent to which the deterrence or the compensation lever are pushed forward.

${ }^{82}$ See Robert H. Lande \& Joshua P. Davis "Benefits From Private Antitrust Enforcement: An Analysis of Forty Cases” (2008) University of San Francisco Law Review 42: 907, who consider that the deterrent value of private damages claims may even be greater than that of public enforcement ("private litigation actually does a better job than the government in advancing the primary goal of the government's enforcement program: deterring illegal corporate behaviour").

\footnotetext{
${ }^{83}$ In practice, the advantages of public enforcement over private enforcement are obvious (information asymmetry of potential private claimants, lack of incentives, low damages paid), see Van den Bergh \& Keske (2008) European Review of Contract Law 3: 471-472.
}

${ }^{84}$ See Van den Bergh \& Keske (2008) European Review of Contract Law 3: 474-475 underline the coordination problems, but it should be noted that public enforcement is also not free from the risks of strategic misuse by competitors. Difficulties (some of them un-surmountable) are detected in harmonizing some of the areas in which it is needed [class actions, multiple awards and passing-on defence), see Van der Dergh \& Keske (2008): 476-485].

${ }^{85}$ Although most application of these rules will concern follow-on actions, they may also be used in hybrid and even in pure stand-alone claims in which access to the file declaring some infringement of the competition prohibitions may be useful for constructing hybrid/mixed claims (see supra note 72).

${ }^{86}$ See recitals 15 and 33 (including specific penalties). 
6.4(a) $]^{87}$, the Directive establishes a principle of subsidiarity (article 6.10), according to which disclosure orders should only proceed as a last resort -when that evidence cannot reasonably be obtained from another party or from a third party" (recital 29). Unless that is the case, competition authorities should not be disturbed.

If the requested evidence cannot be obtained from other sources ${ }^{88}$, in its decision to order disclosure, the court should consider the views of the competition authority regarding "the need safeguard the effectiveness of public enforcement of competition law" [article 6.4(c)] if the competition authority so requests (article 6.10) ${ }^{89}$.

Moreover, in contrast with the rest of the Directive, the rules on disclosure of evidence included in the file of a competition authority are aimed at full harmonization. Although the Directive expressly reaffirms the applicability of the rules on access to information held by EU institutions ${ }^{90}$, it seems that the rules forbidding or delaying access to the case file of the Commission should be regarded as lex specialis that should prevail ${ }^{91}$.

The Directive classifies the evidence in the file of a competition authority in three categories and prescribes clear cut-rules concerning their disclosure.

First, the Directive introduces a blanket prohibition on the disclosure of leniency statements and settlement submissions (article 6.6) (2. $^{92}$ Second, the Directive lists specific pieces of evidence that may only be disclosed after the competition authority has closed its proceedings irrespective of pending appeals, concerning information prepared by parties thereto specifically for the proceedings of the competition authority (including pre-existing documents submitted in support of a leniency application and pre-existing documents obtained by the Commission in an inspection); information drawn up by the competition authority and sent to the parties in the course of its proceedings; and withdrawn settlement

\footnotetext{
${ }^{87}$ Recital 23 expressly excludes "fishing expeditions" in the file of the competition authority ("non-specific or overly broad searches for information that is unlikely to be of relevance for the parties to the proceedings").

${ }^{88}$ However, the principle of subsidiarity does not mean that claimants may use it as a means to overcome the limitations imposed by articles 6.5 or 6.7 , as is stated by article 7 . Although the latter refers to "evidence obtained solely through access to the file of a competition authority", it is reasonable to consider that disclosure orders can neither target leniency nor settlement beneficiaries, asking them to produce the documents indicated therein. Otherwise, the rules on access to the administrative authority could be easily negated of effect.
}

${ }^{89}$ See 926 of Communication from the Commission on Amendments to the Commission Notice on the cooperation between the Commission and courts of the EU MS.

${ }^{90}$ See article 6.2 and recital 20 of Directive and article 15 of TEU and Regulation (EC) 1049/2011 of the European Parliament and the Council, of 30 of May 2001 (OJ 2001 of 31 of May 2001).

${ }^{91}$ See Philip Bentley QC \& David Henry “Antitrust Damages Actions: Obtaining Probative Evidence in the Hands of Another Party” (2014) World Competition 37/3: 277.

92 See $\$ 50$ of ECN Model Leniency Programme (as revised in November 2012) and also Heads of the European Competition Authorities in the resolution of 23 of May 2012 (Protection of leniency material in the context of civil damages actions) stressing the importance protecting of leniency materials in the context of ensuing private litigation. 
submissions (article 6.5). Third, any information that does not fall in the previous two categories can be disclosed at any time (article 6.9).

It is important to note that after the Directive was enacted, the Commission amended its settlement procedures, denying the possibility of withdrawal of settlement submissions ("Settlement submissions cannot be withdrawn unilaterally by the parties which have provided them") ${ }^{93}$, leaving this provision without effect and thereto extending a blanket protection to all settlement submissions ("the Commission will not at any time transmit settlement submissions to national courts for use in actions for damages”) ${ }^{94}$.

In order to ensure strict compliance with the disclosure limitations on evidence in the file of the competition authority for those who may have access to it as parties in the proceedings before the competition authority, the Directive deems inadmissible for use in damages proceedings before national courts the evidence listed in articles 6.5 and 6.6 (article 7.1 and 7.2$)^{95}$.

The blanket prohibition of disclosure of leniency statements and settlement submissions is one of the provisions of the Directive that has provoked the most heated academic debate ${ }^{96}$, a rule which overturns the earlier EUCJ case law on this matter ${ }^{97}$. As is well-known, the EUCJ left the courts with

\footnotetext{
93 |22 of Commission Notice on the conduct of settlement procedures in view of the adoption of Decisions pursuant to Article 7 and Article 23 of Regulation 1/2003 in cartel cases (OJ C 256 of 5 of August 2015).
}

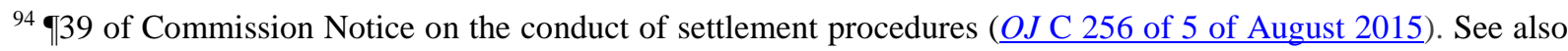
q26a of Communication from the Commission on Amendments to the Commission Notice on the cooperation between the Commission and courts of the EU MS in the application of Articles 81 and 82 ECT (OJ C 256 of 5 of August 2015).

${ }^{95}$ Moreover, to prevent the commercialisation of evidence (see recital 32) the rest of the evidence that is obtained through access to the file of the competition authority and which can freely be used anytime in a damages proceedings claim before a national court can only be used by the person who legally obtained it or who has succeeded in its rights, including those who had acquired that person's claim (article 7.3). See also article 16a of Regulation (EU) 2015/1348 of 3 of August 2015 amending Regulation (EC) No 773/2004 relating to the conduct of proceedings by the Commission pursuant to Articles 81 and 82 of the ECT (OJ L208 of 5 of August 2015); 934 of Communication from the Commission amendments to the Commission Notice on Immunity from fines and

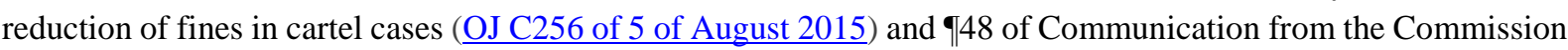
amendments to the Commission Notice on the rules for access to the Commission file (OJ C256 of 5 of August 2015).

${ }^{96}$ See Chirita in Tomljenović, Bodiroga-Vukobrat, Butorac Malnar, Kunda (eds.) EU Competition and State Aid Rules, 168-169; Niamh Dunne “The Role of Private Enforcement Within EU Competition Law” (2014) Cambridge Yearbook of European Legal Studies: 163; Xavier Groussot \& Justin Pierce "Transparency and Liability in Leniency Programmes: A Question of Balancing” in Bersgtröm, Iacovides \& Strand (eds.) Harmonising EU Competition Litigation,163; Björn Lundqvist \& Helene Andersson “Access to Documents for Cartel Victims and Cartel Members- Is the System Coherent?” in Bergström, Iacovides \& Strand (eds.) Harmonising EU Competition litigation, 184; Sebastian Peyer “Access to competition authorities' files in private antitrust litigation” (2015) Journal of Antitrust Enforcement 3: 80-85; Peyer in Marquis \& Cisotta (ed) Litigation and Arbitration in EU Law, 40; Migani (2014) Global Antitrust Review 111.

${ }^{97}$ Dunne Oxford Journal of Legal Studies 2015: 17. 
the power to order disclosure of those documents after weighing the relevant interests involved ${ }^{98}$. The Directive now excludes this possibility, although it provides some safeguards in relation to the blanket disclosure prohibition which has to be interpreted narrowly. It provides room for the national court, upon a reasoned request of the claimant, to check that that some items of evidence do indeed correspond to "leniency statements" and "settlement submissions"99. If, as a result of its assessment, the court deems that part of that evidence is not included within those two categories ${ }^{100}$, it may order their disclosure at any time (pursuant article 6.9) or after the competition authority has closed its proceedings (pursuant article 6.5). The relevance of access to these statements in the context of a damages claim has probably been overrated as it could well be that they would not necessarily contain information valuable in constructing the claim.

\subsubsection{Binding effect of NCAs infringement decisions.}

The protection of leniency and settlement submissions is not the only issue concerning the interplay of damages claims and public enforcers dealt with by the Directive. Infringement decisions by the Commission or NCAs and damages claims the Directive makes provision for follow-on claimants to be able to rely on prior infringement decision adopted by the NCAs.

Drawing on article 16.1 of Regulation 1/2003, claimants may benefit from the spill-over effects of a prior infringement decision by NCAs, or court orders confirming an infringement decision, which will bind the national court. However, the final rule adopted in the Directive is less ambitious than the

\footnotetext{
${ }^{98}$ See $9 \uparrow \mid 30-31$ of judgment of 14 June 2011(Grand Chamber), Pfleiderer AG v. Bundeskartellamt, C-360/09 (ECLI:EU:C:2011:389) and $\uparrow \uparrow$ 134-35 of judgment of 6 June 2013 (First Chamber), Bundeswettbewerbsbehörde $v$. Donau Chemie et al., C-536/11 (ECLI:EU:C:2013:366). But see $\$ 48$ of Opinion of AG Mazák of 16 December 2010, Pfleiderer AG v. Bundeskartellamt C-360/09 (ECLI:EU:C:2010:782) who proposed a similar solution to that finally adopted by the Directive.

${ }^{99}$ See Article 7.7 (and the court can request the assistance of the competent authority and hear the authors of those items of evidence to conduct that assessment, without providing access to anyone else).

${ }^{100}$ See Lundqvist \& Andersson in Bergström, Iacovides \& Strand (eds.) Harmonising EU Competition litigation, 180. For that reason, the Commission and the NCAs should be strict and rigorous in avoiding the introduction of superfluous elements into leniency statements or settlement submissions by applicants only to gain absolute protection for that information. In the same vein, see $₫ 87$ of Judgment of the Court (Great Chamber) of 14 of March 2017, C-162/15P, Evonik Degussa GmbH v. Commission (ECLI:EU:C:2017:205): "the publication, in the form of verbatim quotations, of information from the documents provided by an undertaking to the Commission in support of a statement made in order to obtain leniency differs from the publication of verbatim quotations from that statement itself. Whereas the first type of publication should be authorised, subject to compliance with the protection owed, in particular, to business secrets, professional secrecy and other confidential information, the second type of publication is not permitted in any circumstance."
} 
draft provision contained in the 2013 proposal which heralded a "EU-wide binding effect" 101 , as the Directive provision only extends to decision by domestic NCAs and appeal courts ${ }^{102}$.

Although MS are free in their transposition measures to set the same effect for both domestic and foreign NCAs (like Germany) ${ }^{103}$, the Directive only requires foreign NCA decisions be deemed to be prima facie evidence of an infringement. As such, the evidentiary value of those decisions is limited, as that "finding can be assessed as appropriate, along with another evidence adduced by the parties" (recital 35). The different regime established for the binding effect of domestic and foreign NCAs' infringement decisions is unsatisfactory and it runs contrary to the principles of legal certainty and procedural efficiency which theoretically justify it, and it may lead not only to duplication of procedures and ensuing costs, but also to inconsistencies in the application of the EU competition rules ${ }^{104}$.

\section{Assessment of the Directive. Scope and texture of its rules: neglected issues, limitations \& inherent biases.}

The Damages Directive tackles the task of positively harmonizing the rules on antitrust damages claims, but in doing so, it neglects some relevant issues that would be required for claims to be raised and for them to be successful (infra §4.1). In addition, it offers a limited treatment of other issues which will led to uncertainty in the implementation of the Directive by MS (infra §4.2). Finally, its rules are skewed in their drafting in favour of some type of claims (infra §4.3), and this may affect their implementation and could undermine the goals of the Directive, when considering their application to claims which are only partially considered by the Directive and not fully developed (f.e., claims victims of infringements different from cartels; claims by upstream victims). It is doubtful that it leads to a uniform level playing field for antitrust damages claims across the EU (infra §4.4).

101 See also q2.3 White Paper and Staff Working paper 2008 (\$ף143-145).

102 The rule that the court cannot deviate from the domestic NCA's final decision also exists in the UK (Section 58A of the Competition Act 1998).

${ }^{103}$ Regarding German law, such a rule has been in force since the $7^{\text {th }}$ Amendment of the GWB in 2005 (section 33.4), see Wolfgang Wurmnest "Private Antitrust Litigation in Germany after the Reform of the Law against Restraints of Competition” (2005) German Law Journal 6/8: 1185-1186.

${ }^{104}$ See Truli (2016) Journal of European Competition Law \& Practice 7: 306; Massimo Merola \& Leonardo Armati "The Binding Effect of NCA Decisions under the Damages Directive: Rationale and Practical Implications" (2016) Italian Antitrust Review 3/1: 101-102 and Evelin Pärn-Lee "Effect of National Decisions on Actions for Competition Damages in the CEE Countries" (2017) Yearbook of Antitrust and Regulatory Studies 10/15: 184$\underline{185}$. 
Of course, given the essence of a Directive as a flexible legal instrument, and considering that some of its clauses only impose minimum harmonization ${ }^{105}$, the possibility exists for MS to further extend the scope of the new rules or shape them to be more comprehensive and effective ${ }^{106}$.

\subsection{Shortcomings and neglected issues.}

First, the Directive singles out monetary damages claims as the only type of possible private enforcement action covered by these rules. The Directive does not apply to other private claims (declaratory actions, orders to cease and desist of infringement, requests for interim measures, restitution or unjust enrichment claims or claims for compensation in nature) which may be relevant in addressing the wrongs that may be provoked by antitrust infringements ${ }^{107}$. The focus on damages claims can probably be better explained and understood by considering the Directive's slant towards cartel damages claims (infra §4.3). Although in many cases the interest of those harmed by an antitrust infringement may be better served and satisfied with those alternative remedies, they are left out of the scope of the Directive $^{108}$. Nonetheless, MS are free to extend some of the rules of the Directive to these other types of action ${ }^{109}$.

Secondly, even within the realm of damages claims, although the Commission had noticed in the works that led to the adoption of the Directive that costs/funding of claims and collective redress were two of the challenges that should be addressed in promoting antitrust damages claims in the $\mathrm{EU}^{110}$, there is specific provision for neither in the Directive. The Directive is silent in this regard and, in doing so, it

${ }^{105}$ See Piszcz (2017) Market \& Competition Law Review 1:102 (expressly recognized by the Directive, for example on access to evidence in article 5.8 -"this Article shall not prevent Member States from maintaining or introducing rules which would lead to wider disclosure of evidence"- or on the binding effect of final decisions by other NCAs in article 9.2 - "at least prima facie evidence" or, finally, regarding the limitation period in art. 10.3"at least five years").

${ }^{106}$ See Alison Jones "Private Enforcement of EU Competition Law: A Comparison with, and Lessons from, the US” in Bersgtröm, Iacovides \& Strand (eds) Harmonising EU Competition Litigation, 38. That is also the suggestion of Peyer (2016) European competition Journal 12: 26 ("national governments must regulate private antitrust enforcement beyond the narrow scope of the Antitrust Damages Directive”).

${ }^{107}$ See Dunne Oxford Journal of Legal Studies 2015: 25; Anna Piszcz "Piecemeal Harmonisation Through the Damages Directive? Remarks on What Received Too Little Attention in Relation to Private Enforcement of EU Competition Law” (2015) Yearbook of Antitrust and Regulatory Studies 8/12:79-98.

${ }^{108}$ However, nothing prevents victims from relying on national law restitutory remedies -if available (and which may be easier to argue and more effective)- though indirect purchasers will resort to the tools provided by the Directive, see Magnus Strand "Beyond the Competition Damages Directive: What Room for Competition Law Restitution?” in Bersgtröm, Iacovides \& Strand (eds) Harmonising EU Competition Litigation, 281-282 \& 292293

${ }^{109}$ It is true, however, that the focus on damages actions can be traced to the case-law of the ECJ, being the issue that was brought before its attention in most of the cases.

${ }^{110}$ See Ashurst Report 2004 42-46 and 90-96; Staff Working paper 2005 १ๆ188-220: Staff Working Paper 2008 ๆๆ|28-32; 38-64 and 241-267. 
neglects two crucial issues that would facilitate successful compensation (but which, at the same time, are more politically sensitive and problematic) ${ }^{111}$. The nonchalance of EU institutions regarding antitrust collective redress and aggregation of claims has its more recent corollary in its "New deal for consumers" package, in which the proposal of a Directive for representative actions does not foresee its application to antitrust damages claims ${ }^{112}$.

Thirdly, although the core of the Directive recognizes the right to full compensation, some of the crucial elements for the effectiveness of that right are not harmonized in the Directive. The fault and causation requirements for damages claims will continue to be governed by national law ${ }^{113}$, and may vary from MS to MS, and national rules will also determine whether tort/contract law is available as the legal basis for the claim ${ }^{114}$.

\subsection{Limited treatment.}

Litigation is costly and out-of-court solutions may be the best way to address damages claims by antitrust victims. Thus, arguably consensual dispute resolution should be the favoured channel for claims. However, the Directive clearly looks at legal claims brought before national courts as the main tool through which victims' compensation is to be assured, with minimal reference to non-judicial claims and to consensual dispute resolution (see supra §3.3.6) ${ }^{115}$.

Indeed, in seeking some minimum harmonization of the rules for antitrust claims, the Directive fails to provide a comprehensive and entirely coherent framework of substantive and procedural rules that would promote compensation.

First, together with some substantive rules on the right to compensation of victims of competition infringements, the Directive introduces several procedural rules aimed at strengthening that right.

${ }^{111}$ See Dunne (2014) Cambridge Yearbook of European Legal Studies: 165 and Peyer in Marquis \& Cisotta (ed.) Litigation and Arbitration in EU Law, 36.

${ }^{112}$ See article 2.1 of Proposal for a Directive of the European Parliament and of the Council on representative actions for the protection of the collective interests of consumers, of 11 April 2018 (COM/2018/0184 final); Directive 104/2014 is not contained in the list of rules to which it is applicable (Annex 1).

${ }^{113}$ See Katri Havu "Causation and Damage: What the Directive Does Not Solve and Remarks on Relevant EU Law” in Vladimir Bastidas, Marios Iacovides \& Magnus Strand (eds) Competition Damages Directive, First Experiences of the New Regime, Hart 2018 (forthcoming) and "Fault in EU Competition Law Damages Claims" (2015) Global Competition Litigation Review 8/1:1-13.

${ }^{114}$ See recital 13 of Directive; Ashton \& Henry Competition Damages Actions in the EU, 32-34; Miguel Sousa Ferro "Antitrust Private Enforcement in Portugal and the EU: the Tortuous Topic of Tort” (2016) Global Competition Litigation Review 4:140 and Strand (2017) European Competition Law Review 38: 204-206.

${ }^{115}$ Given the experience in the U.S. and in some MS (see Barry J. Rodger "Why Not court? A Study of follow-on actions in the UK" (2013) Journal of Antitrust Enforcement 1:104-131, the focus of the Directive may be mistaken as out-of-court settlements may well be a prevalent and successful outcome of an effective system for antitrust damages claims. 
However, concerning the distinction between substance and procedure, which will prove essential in deciding the transitory regime of the Directive (article 22), the Directive leads to unnecessary uncertainty, as the classification of rules according to this hybrid categorisation may vary from MS to MS ${ }^{116}$.

On the other hand, the positive harmonization carried out by the Directive affects some features of the right to compensation and some rules regarding discovery and access to evidence, but it is far from an exhaustive regime, and many relevant issues are left open and to be solved by the national rules of each Member State (respecting the principles of effectiveness and equivalence) ${ }^{117}$. Likewise, the Directive introduces some rules on the interaction of public enforcement and private damages claims (mainly on the binding force of the NCAs final decisions for national courts and to restrict access to the file of the Commission or NCAs) ${ }^{118}$ but does not provide a complete set of answers to many of the issues that may occur in practice ${ }^{119}$.

\subsection{Inherent biases.}

The neglected issues and the limitations discussed above are explicitly acknowledged by the Commission and the Directive itself. Indeed, most of them were pointed out and studied -one way or another- in the preparatory works that led to the adoption of the Directive. But the final rules themselves suffer from three subtle inherent biases which affect how some of them are fashioned and which may have an impact on their implementation by MS and their interpretation by national courts.

First, although the Directive governs damages claims for any competition infringement, many of its rules are applicable primarily in relation to cartels, and overall the Directive was evidently drafted with cartels in contemplation as the type of infringement that gives rise to compensation ${ }^{120}$. Indeed, this bias seems to be well founded as cartels are the infringement in which less private enforcement exists and damages being the more plausible private remedy in those cases ${ }^{121}$. Moreover, cartels are

\footnotetext{
116 See also Assimakis P. Komminos “Civil Antitrust Remedies Between Community and National Law” in Catherine Barnard \& Okeoghene Odudu (eds.) The Outer Limits of European Union Law, Hart 2009, 372 ["it is not always clear in the EU Member States' legal systems where substance stops and procedure begins or vice versa" (citation omitted)].
}

117 See Dunne (2014) Cambridge Yearbook of European Legal Studies: 162 and Howard (2014) Journal of European Competition Law \& Practice 4: 456.

${ }^{118}$ Additionally, the Directive accommodates the starting of the limitation period in follow-on claims (article 10.4) and it also recognizes possible consultation by the court with NCAs regarding the quantification of harm (article 17.3).

${ }^{119}$ For example, concerning the possible stay of damages proceedings until a final decision is adopted by an NCA. Similarly the limited cross-border binding force of foreign court and NCAs infringement decisions (supra §3.3.9), may lead to different procedural standards.

${ }^{120}$ See Dunne (2014) Cambridge Yearbook of European Legal Studies: 145 and 168-185.

${ }^{121}$ See Sebastian Peyer “Cartel Members Only- Revisiting Private Antitrust Enforcement in Europe” (2011) International \& Comparative Law Quarterly 60/3: 649-650 \& 653. 
unambiguous anti-competitive actions which infringe competition law, in which the risk of error or unmeritorious litigation is minimal or at least significantly reduced.

On the other hand, those risks are greater in the case of non-cartel competition infringements, where the ambiguity of the prohibitions may, some would argue, lead to nuisance suits or erroneous damages awards. Nevertheless, victims of other type of competition infringements, like unlawful vertical restraints or abuses of dominance, may also be entitled to compensation, but the characteristics of these infringements raise specific issues concerning who the injured may be, their legal standing to seek damages and the identification and quantification of the harm suffered that are not tackled in the Directive $^{122}$.

Secondly, although damages claims may follow previous decisions of the European Commission or NCAs, they may also be stand-alone claims by victims without a prior infringement finding by the public enforcement authorities. Many provisions of the Directive consider mainly "follow-on" claims (e.g., articles 6, 7 and 9), and that will effectively be the case for most cartel claims, but it is of course possible that for other type of competition infringements "stand-alone" damages claims may be initiated ${ }^{123}$. All in all, in underlying its concern with the interaction of damages claims and prior actions by public enforcers (recital 6), the Directive's rules are slanted towards follow-on claims rather than stand-alone actions ${ }^{124}$.

Although many of the Directive's provisions may also be applied to stand-alone claims, the Directive was clearly drafted having primarily in mind follow-on claims ${ }^{125}$. This arguably shows that the EU legislator was not wholly committed to the promotion of stand-alone private enforcement, perhaps partly because its foremost concern continues to be the protection of public enforcement, and partly because of a fear of excessive litigation if the effectiveness of stand-alone claims was more clearly provided for. ${ }^{126}$

Thirdly, the right to full compensation is extended to all victims of competition infringements, direct and indirect, but the Directive's rules mainly address cases involving victims located downstream,

\footnotetext{
${ }^{122}$ See Dunne (2014) Cambridge Yearbook of European Legal Studies: 145 and 168-185175-179; Mark-Oliver Mackenrod "Private incentive, optimal deterrence and Damage claims for Abuses of Dominant Positions- The Interaction between the Economic Review of the Prohibition of Abuses of Dominant Position and Private Enforcement“ in Mark-Oliver Mackenrodt, Beatriz Conde Gallego \& Stefan Enchelmaier (ed.) Abuse of Dominant Position: New Interpretation, New Enforcement Mechanisms?, Springer 2008, 165-189.
}

${ }^{123}$ Correspondingly, Howard (2014) Journal of European Competition Law \& Practice 4: 463. See also Kai Hüschelrath \& Sebastian Peyer "Public and Private Enforcement of Competition Law: A Differentiated Approach" (2013) World Competition 36/4: 603-610. Indeed, damages claims on abuse of dominance cases may be standalone claims and there is always the risk of them being unfounded or meritless, see Mackenrod in Mackenrodt, Conde \& Enchelmaier (ed.) Abuse of Dominant Position? 185.

${ }^{124}$ See Howard (2014) European Competition Law Review 35:52; Thiede (2017) China Antitrust Law Journal 5: $\underline{238}$.

${ }^{125}$ See Juška (2017) International Review of Intellectual Property \& Competition Law 49/1: 79 and 84.

${ }^{126}$ See Marcos \& Sánchez Graells (2008) European Review of Private Law 3-2008: 480. 
although there is sporadic mention of those rules extending to upstream victims ${ }^{127}$, when the infringement affects suppliers. Accordingly it remains unclear if the Directive's provisions drafted with downstream victims in mind (both indirect purchasers and umbrella victims) can be applicable to victims located upstream ${ }^{128}$, not only in buyer cartels or abuses of dominance by a monopsonist ${ }^{129}$, but also in standard selling infringements ${ }^{130}$. In addition, the singularities and complexities where the harm flows upstream are left un-tackled by the Directive ${ }^{131}$.

\subsection{Uniform EU playing field?}

The Directive aims at providing minimal harmonization of rules governing antitrust damages claims in the $\mathrm{EU}^{132}$, but given the piece-meal approach followed and the vague terms in which many of its provisions are fashioned, there will inevitably remain considerable diversity in the rules and proceedings in force in different MS ${ }^{133}$.

Although the principles of effectiveness and equivalence have been expressly codified in the Directive (article 4), the institutional and procedural autonomy of MS, and their differing cultures and experiences in this context, will lead to different environments for damages claims in each MS. Moreover, such diversity may have an impact on the likelihood of successful claims, and given the latitude provided by the EU's international private law rules on jurisdiction and choice of law ${ }^{134}$, there

${ }^{127}$ See recital 43 and articles 2.4, 11.4.a), 11.5 and 11 (in total 6 references to "providers”, one to "suppliers" and another one to "supply to the infringer"). In the 2013 Proposal many of these rules were bundled together (article 14. Loss of profits and infringement at the supply level) but this was revised during the legislative process. See also Commission Staff Working Document Practical Guide Quantifying Harm in Actions for Damages Based on Breaches of Article 101 or 102 of the TFEU accompanying the Communication on quantifying harm in actions for damages 12 (footnote 26) and Franck P. Maier-Rigaud “Toward a European Directive on Damages Actions” (2014) Journal of Competition Law \& Economics 10/2: 358 and Frank P. Maier-Rigaud \& Ulrich Schwalbe "Quantification of Antitrust Damages" in Ashton \& Henry Competition Damages Actions in the EU, 221-223

${ }^{128}$ See Howard (2014) Journal of European Competition Law \& Practice 4: 459.

${ }^{129}$ See Roger D. Blair \& Wenche Wang “Buyer Cartels and private enforcement of antitrust policy” (2017) Managerial Decision Economics 38: 1185-1192

${ }^{130}$ See Eckard Bueren \& Florien Smuda “Suppliers to a sellers' cartel and the boundaries of the right to damages in U.S. versus EU competition law” (2017) European Journal of Law \& Economics 18-20.

${ }^{131}$ See Bueren \& Smuda (2017) European Journal of Law \& Economics 30-41. In the case of buyer cartels see Blair \& Wang (2017) Managerial Decision Economics 38: 1186-1197 and 1990-1991.

${ }^{132}$ See recitals $1,7,8$ and 9.

133 See Dunne Oxford Journal of Legal Studies 2015: 31; Katri Havu “Quasi-coherence by Harmonisation of EU Competition Law-related Damages Actions?” in Pia Letto-Vanamo \& Jan Smits (eds) Coherence and Fragmentation in European Private Law, Verlag Dr Otto Schmidt 2012, 31-31 ("the souls of the law may differ between different Member States but also from the soul the EU wished the law to have [...] Divergences between the souls of the law in the different Member States depends on the respective contexts in each Member State").

${ }^{134}$ See Wolfgang Wurmnest "International jurisdiction in competition damages cases under the Brussels I Regulation: CDC Hydrogen Peroxide” (2016) Common Market Law Review 53: 235-236. 
will be still room for forum shopping for the best legal rules and processes. After the Directive is implemented, there will only be partial or limited harmonization, and substantial legal differences will subsist and, therefore, forum shopping will continue ${ }^{135}$. It is unlikely that the Directive will change that litigational reality ${ }^{136}$.

Claimants will seek to litigate in those MS where the legal rules and courts have shown to be more receptive to these types of claims, and legal cost considerations will be important in choosing a particular jurisdiction. Likewise, defendants can still benefit from distortive litigation strategies to delay claims (torpedoes).

\section{The implementation of the Directive.}

As is known, the Directive is binding as to the result to be achieved, but it leaves MS the choice of the means of fulfilling the requirements in their national law, including the form, instruments and methods to be used (Article 288 of TFEU).

MS should have implemented the Antitrust Damages Directive by 27 of December 2016 (article 21.1). MS should also notify the Commission of the provisions adopted for implementation and transposition.

The Commission is in charge of monitoring compliance with the Directive, for which notifications or reports of its implementation by MS are essential (art. 21.2). Most MS implemented the Directive in a delayed fashion after the deadline set for transposition. Only seven MS had implemented the Directive in time (Denmark, Finland, Hungary, Lithuania, Luxembourg, Slovakia and Sweden), and this prompted notices being issued to the remaining MS by the Commission ${ }^{137}$. Portugal was the last MS to implement

\footnotetext{
${ }^{135}$ See Mihail Danov \& Florian Becker “Introduction: The Enforcement Pattern Shaping Litigants' Strategies” in Mihail Danov, Florian Becker \& Paul Beaumont (eds) Cross-Border EU Competition Law Actions, Hart 2013, 146; Dunne (2015) European Law Review 40/4:596; Sofia Oliveira Pais \& Anna Piszcz "Package on Actions for Damages Based on Breaches of EU Competition Rules: Can One Size Fit All?” (2014) Yearbook of Antitrust and Regulatory Studies 7/10: 233; Havu in Letto-Vanamo \& Smits (eds) Coherence and Fragmentation in European Private Law, 34; Migani (2014) Global Antitrust Review 105-107 and Truli (2016) Journal of European Competition Law \& Practice 7: 303.

136 See Howard “(2014) European Competition Law Review 35: 55 ("More likely, given the extent of legal uncertainty and adverse cost implications resulting from the burden of proof, we can expect increased use of ADR mechanisms to remove these claims from the courts' jurisdiction altogether. That outcome is not consistent with the Commission's desired aims of achieving a level playing field across the EU and an open internal market for competition litigation, but it is likely to be the practical reality for speedy resolution of competition damages claims in the near future. So more to do with damage limitation than damages litigation”).
}

${ }^{137}$ Formal notice letters were sent by the Commission to twenty-one MS which failed to communicate full transposition by 18 of January 2017 (2017/0189, 24 of January 2017). On July 2017 the European Commission sent reasoned opinions to Bulgaria, Cyprus, the Czech Republic, Greece, Latvia, Malta and Portugal for failing to notify the Commission of their national transposition measures (see European Commission, Fact Sheet: July Infringements Package, 13/07/2017). Finally, in March 2018 the Commission closed the infringement proceedings 
the Directive, in May 2018.

The delay in implementation of the Damages Directive has prompted doubts concerning the direct effect of some of its provisions prior to effective implementation has taken place (In the period running from deadline to effective transposition $)^{138}$.

On the other hand, as the Directive is also EEA relevant, it also needs to be incorporated in the EEA Agreement for it to be applicable in EEA Member States (Iceland, Liechtenstein and Norway) ${ }^{139}$.

Apart from the timeliness of its transposition by the MS, it is worth considering in general terms the risk of questionable or defective transposition by MS of the Antitrust Damages Directive ${ }^{140}$. Transposition is necessary for implementing the Directive, but it probably requires more than formal implementation or compliance with its rules, given its aim of enhancing the successful pursuit of antitrust damages claims.

Indeed, the risk of MS' non-compliant implementation of the Antitrust Damages Directive is exacerbated by the vague and indeterminate terms in which some of its rules are drafted and by the frequent appeal to the principle of effectiveness and the duty of cooperation. In many instances, as the reports in Part II show, MS seem to have followed a formal and apparently compliant approach leading to mindless copying of some of the Directive's open provisions into domestic law ${ }^{141}$, calling upon national Courts to comply with the principle of effectiveness and the duty of cooperation in adopting their decisions when the claims may be brought before them.

it had started in 2017 against 18 MS (Austria, Belgium, Cyprus, Croatia, the Czech Republic, Estonia, France, Germany, Ireland, Italy, Latvia, Malta, the Netherlands, Poland, Romania, Slovenia, Spain and the United Kingdom) after they had finally transposed the Directive (March infringements package: key decisions, 08/03/2018)

${ }^{138}$ However, the lag in the timely implementation of the Antitrust Damages Directive does not seem singular or exceptional, but rather reflects a common trend, see the most recent scoreboard (and previous editions) of the General Secretariat of the European ammission at http://ec.europa.eu/community_law/directives/directives_communication_en.htm. On this, see Michael Kaeding "Determinants of Transposition Delay in the European Union” (2006) Journal of Public Policy 26: 229-253.

${ }^{139}$ Interestingly, the Borgarting Court of Appeal (Borgarting lagmannsrett) of Norway, has requested on $24^{\text {th }}$ November 2017 an Advisory Opinion from the EFTA Court (Nye Kystlink AS v, Color Group AS \& Color Line $A S, \underline{E}-10 / 17)$ in which, the EFTA Court is asked whether the principles of effectiveness and equivalence are respected by the Norwegian national limitation rules which set an expiry period of three years after the date on which the injured party obtained or should have procured necessary knowledge about the damage and the responsible party irrespective of the fact was a parallel EFTA Surveillance Authority (ESA) proceeding ongoing (the Directive 2014/104 is mentioned in the reference although not applicable at that point).

${ }^{140}$ Several factors (related to the Directive itself but also to each MS) may affect the process and timing of implementation of the Directive, the resulting national rules and their conformity with the Directive, see Thomas Köning \& Lars Mäder "Non-conformable, partial and conformable transposition: A competing risk analysis of the transposition process of directives in the EU15” (2009) European Union Politics 14/1: 52-54 and 64-65.

141 Following both a literal and minimalistic technique, see Richard Král "On the choice of methods of transposition of EU Directives” (2016) European Law Review 41/2: 221-225 and 233-234. 
As the long process leading to the adoption of the Antitrust Damages Directive demonstrates, the final text of the Directive appears to be a compromise between the MS and the European Commission and it balances multiple interests. The Directive contains too many loosely worded provisions and few clear-cut rules ${ }^{142}$. This ambiguity in drafting can raise the issue of questionable or defective transposition by MS, and for that reason the delegation of the interpretation and application of some of its broad and vague provisions to the national courts defers the potential risk of non-compliance to the judicial stage ${ }^{143}$. In other words, as some of the new rules encroaches national legal traditions and institutions, it may be that national courts act as gatekeepers of domestic traditions in opposition to the requirements of the Directive $^{144}$.

The Directive calls for national law to be adapted, as it seeks to provide some minimal harmonization of basic substantive and procedural rules across the EU. Of course, this adaptation is made more difficult if the Directive is complex, and the complexity of the Antitrust Damages Directive is shown not only by the ambiguity of some of its rules but also by the extensive number of recitals.

The Directive contains 24 articles and 56 recitals. Some of the recitals include more than mere criteria for interpretation of the Directive's rules and they seem to carry additional normative force (for example, recital 12 concerning the calculation of interest, see supra §3.3.1 or recital 37 regarding the contribution rule among co-infringers, see supra §3.3.4) ${ }^{145}$.

${ }^{142}$ See Truli (2016) Journal of European Competition Law \& Practice 7: 311 ("It regularly includes vague declarations of objectives bordering to wishful thinking").

${ }^{143}$ This is a problem raised by the literal transposition when -as occurs with some provisions in the Damages Directive- its provisions are not "terminologically and conceptually coherent with national laws", see Král (2016) European Law Review 41/2: 224 (and therefore, "it would lead to ambiguities of interpretation and application endangering the proper operation of national transposition measures").

144 This is especially the case given that the "law of obligations and civil liability may be described as resistant to changes imposed from the outside", Havu in Letto-Vanamo \& Smits (eds) Coherence and Fragmentation in European Private Law, 40 ("national courts face a difficult task of applying law that is partially based on traditional goals of national tort law and partially on the instrumental nature of EU competition law-based damages claims", id. 41).

${ }^{145}$ Recitals do not have autonomous legal force, although they may help to resolve or interpret ambiguities in legal provisions. They can assist in establishing the objective of a provision [ $₫ \uparrow \mid 37-39$ pf EUCJ judgment (Sixth Chamber) of 26 of June 2001, BECTU C-173/99 (ECLI:EU:C:2001:356)] or its scope [952 of EUCJ judgment (Grand Chamber) of 27 of November 2007 (ECLI:EU:C:2007:714)]. Besides, they do not have "binding legal force and cannot be relied on as a ground for derogating from the actual provisions of the act in question or for interpreting those provisions in a manner clearly contrary to their wording..." q54 of EUCJ judgment (Fifth Chamber) of 19 of November 1998, Gunnar Nilsson, Per Olov Hagelgren \& Solweig Arrborn, C-162/97 (ECLI:EU:C:1998:554). Indeed, according to EUCJ judgment (Fifth Chamber) of 24 of November 2005, Deutsches Milch-Kontor, C136/04 (EU:C:2005:716) "it is sufficient to recall that the preamble to a Community act has no binding legal force and cannot be relied on either as a ground for derogating from the actual provisions of the act in question or for interpreting those provisions in a manner clearly contrary to their wording “( $(\$ 32)$.See also $\$ 47$ of EUCJ judgment (Sixth Chamber) of 9 of February 1995, Edouard Leclerc-Siplec, C-412/93 ( ECLI:EU:C:1995:26) ; $\uparrow 30$ of EUCJ judgment (Sixth Chamber) of 25 of November 1998, Manfredi v. Puglia, C-308/97 (ECLI:EU:C:1998:566). In sum, as Advocate General Léger said in his Opinion delivered the 5 of October of 2005, Commission v. Italy, C- 
The practice of introducing "shadow" rules in the recitals of Directives, supplementing their operative rules, is not unknown in EU Law, but of course it affects both the transposition of the Directive and the interpretation that courts should give to the implementing rules ${ }^{146}$. Additionally, some of the recitals in the Damages Directive reflect the compromises adopted during the legislative process, whereby some proposals and provisions did not reach the final operative text, and that increases the risk of mis-interpretation ${ }^{147}$.

The quality of the Directive itself (unclear and vague in some aspects) may explain some of the problems encountered by MS in its implementation ${ }^{148}$, together with the conflict between certain Directive provisions and some long-standing traditions and rules of MS law ${ }^{149}$. In addition, the complexity in its implementation can be measured by the revolutionary changes that its provisions introduce in some MS (e.g., disclosure of evidence) making its implementation complicated.

It is unlikely that MS could be found non-compliant due to opposition or resistance to the Antitrust Damages Directive. Although some of the provisions contain novelties that may lead to the introduction of relevant changes in national law, it does not seem that any of those can be deemed unwanted by MS ${ }^{150}$. Indeed, as it has been pointed before, the Directive does not contain any provisions regarding the funding of claims and collective redress, which a majority of MS considered undesirable.

Besides, it neither seems that MS can be found to be non-compliant due to gold-plating or issue linkage as other issues -related or extraneous to the Directive- were included in its transposition ${ }^{151}$. It seems that the most plausible scenario is that of non-compliance due to interpretation problems ${ }^{152}$. As most MS has copied the Directive's provisions in national law, and some of those provisions are notably

110/05 (ECLI:EU:C:2006:646): “although the preamble to a directive in principle may give the Court information as to the legislature's intention and the meaning to be given to the measure's provisions, the fact remains that, where a concept set out in a recital is not given concrete expression in the actual body of the directive, it is the terms of the latter that must predominate“ (\$65).

${ }^{146}$ See Kaeding (2006) Journal of Public Policy 26: 236 (recitals as a parallel type of law-making).

${ }^{147}$ Compromises are shown by the heterogeneity of rules in MS, and this has led to the failure to harmonize many contested issues. This further introduces uncertainty as regards compliance by MS and a contest between procedural autonomy and. effectiveness/equivalence

${ }^{148}$ See Bernard Steunenberg \& Mark Rhinard "The transposition of European law in EU member states: between process and politics” (2010) European Political Science Review 2/3: 501 (and 510). Twelve more recitals were added to the original proposal of the Directive along the legislative process, which probably explains the complexity of some of the provisions adopted.

${ }^{149}$ See Steunenberg \& Rhinard (2010) European Political Science Review 2: 508 [full assessment of compliance requires looking at the existing national rules and their interaction with the Directive (the so-called the "goodness of fit”)]

\footnotetext{
${ }^{150}$ See Gerda Falkner, Miriam Hartlapp, Simone Leiber \& Oliver Treib "Non-Compliance with EU Directives in the Member States: Opposition through the Backdoor?” (2004) West European Politics 27/3:456-457

${ }^{151}$ See Falkner, Hartlapp, Leiber \& Treib (2004) West European Politics 27: 461.

${ }^{152}$ See Falkner, Hartlapp, Leiber \& Treib (2004) West European Politics 27: 463
} 
vague or require complex interpretations, doubts of the compatibility of national law with the Directive will be shifted to national courts, which will it is suggested inevitably lead to preliminary rulings being requested by those courts from the EUCJ. ${ }^{153}$

\section{Conclusions}

This paper has looked at the Antitrust Damages Directive as the latest legal instrument that crystalizes the evolution of EU competition law enforcement. The Directive can be considered as another step in the process of progressive decentralization of enforcement, in which for the first time victims of antitrust infringements are given a main character in enforcing the competition prohibitions. The Directive firmly empowers them to claim damages against infringers if there had been any harm that can be proven and traced back to the infringement. In this vein it consolidates the case-law of the EUCJ on this regard and ultimately also reflects some influence of U.S. law ${ }^{154}$, where damages claims are the predominant way of making the antitrust prohibitions effective. Following that inspiration ${ }^{155}$, from now on victims of antitrust violations are enlisted as "private attorney generals" to complement the enforcement actions of the European Commission and the NCAs ${ }^{156}$.

The Directive enshrines the right to compensation of anyone harmed by a competition infringement and introduces several rules regarding the content, the features and the exercise of such right before national courts, but it does not change the traditional dynamics of the relationship between EU law and MS' national laws regarding the conditions in which victims' claims have to be exercised. National rules on remedies, procedure and institutions will be followed as long as the principles of effectiveness and equivalence are respected. Thus, it is clear that it would be against the Directive if the national rules made the right to compensation impossible or excessively difficult.

However, the Directive marks a meaningful retreat from the principle of MS remedial/procedural autonomy, by introducing several rules that go beyond the mere recognition of the existence of right to compensation in various respects (amount of compensation, statute of limitations, multiple liability,

\footnotetext{
153 The calls for these are unanimous in the first comments prompted by the Directive itself, see Howard (2014) Journal of European Competition Law \& Practice 4: 464; Odudu \& Sánchez Graells in Giliker (ed) Research Handbook on European Tort Law, 166 and 174 and Strand (2017) European Competition Law Review 38: 204205.

154 The starting point in the U.S.A. is section 4 of Clayton Act (15 U.S.C. §15): “any person who shall be injured in his business or property by reason of anything forbidden in the antitrust laws may sue therefor (...) and shall recover threefold damages (....)”. See Dunne Oxford Journal of Legal Studies 2015: 21; Maier-Rigaud (2014) Journal of Competition Law \& Economics 10: 347.

${ }^{155}$ See Judgment of US Court of Appeals for the Second Circuit of 8 of February 1943, Associated Industries of NY State Inc v. Ickes, 134 F.2d 694, 704 (2d cir. 1943).

${ }^{156}$ See Arianna Andreangeli "From Complainant to Private Attorney General: The Modernisation of EU Competition Enforcement and Private Antitrust Action before National Courts” in Michael Dougan \& Samantha Currie (eds.) 50 years of the European Treaties: Looking Back and Thinking Forward, Hart 2008, 229-254.
} 
standing and harm quantification and binding force of final decisions of NCAs). MS will have to incorporate those rules to comply with the Directive. In addition, the Directive further introduces a discovery process to be inserted in the domestic civil procedure rules that for most MS is revolutionary. It will be a challenge for the parties and for courts to adequately put them into practice when the national legal system is not familiar with these tools.

The harmonization sought by the Directive is limited and fragmented and it extends only some of the issues relevant for the exercise of damages claims. It presents an incoherent framework, regulating some issues but does not consider or even mention other relevant aspects. At the same time, the Directive's provisions are inherently biased in addressing mainly issues raised by follow-on claims, damages caused by cartels and harm flowing downstream. Again, on the matters in which the Directive is silent, MS' domestic rules will continue to govern subject to the principles of effectiveness and equivalence.

In addition, many of the Directive's provisions that encroach upon MS remedial/procedural autonomy are drafted in a generic or vague manner and this will surely raise interpretation problems in the future, which may themselves render damages claims difficult. Questions remain in relation to many issues dealt with by the Directive, starting with its temporal scope; but uncertainties also subsist in crucial aspects of multiple liability and claims by indirect victims when harm has flown along the supplydistribution chain (and the passing-on defence). Significantly, the most clear-cut and concise provisions of the Directive are those aimed at safeguarding public enforcement of competition law by restricting access to evidence in the file of the competition authorities provided by immunity beneficiaries and by parties that entered into a settlement agreement with a competition authority. The Directive sets absolute and temporal limits on the access to the files of their cases to prevent public enforcement of competition law (leniency and settlement included) from being disturbed. Nevertheless, even those rules may be controversial, as they run against the objective of facilitating damages claims as the prompt disclosure of information in the file of the competition authority may ease the burden of proof and quantification of the harm by victims.

In comparison with the pre-existing position, it may be said that the Directive contributes some improvements to the rules and legal tools for making damages claims successful. However, the practitioner and academic critique of many of its provisions may be justified. The Directive is shortsighted in omitting any provision to deal two of the crucial issues that the Commission's preparatory works identified as being necessary for damages claims to be brought -funding of claims and collective redress-. No measures were ultimately introduced, and neither are they expected in the near future. Moreover, as indicated before, some of the legal solutions provided in the Directive appear too vague or too complex which will inevitably lead to interpretation problems that may negatively affect the incentives to bring damages claims or their outcome.

Still, a more positive assessment is feasible. Focusing on its shortcomings, legal imperfections and loopholes would not provide a full and accurate appraisal of its potential impact.

First, the Directive is the most recent step in the EU policy of enhancing antitrust enforcement by looking at a particular aspect -damages claims by victims- which was not previously covered by EU rules, but it does not mean that it is the final or definitive step. At this stage, this is the most that the 
compromise of different interests affected could deliver ${ }^{157}$. The Directive itself provides for its review by the end of 2020 and, depending on its impact, amendments can be proposed to correct any weaknesses identified and to improve its rules (article 20).

Second, and more importantly, the Directive is an achievement in itself (as a corollary of the works of the Commission on this regard) as a significant component in the competition policy discussion in the EU. The adoption of the Directive and its implementation in MS has created momentum and it has publicised the availability of damages claims within the enforcement landscape. The debate around the passing of the Directive has undoubtedly raised business awareness of the use of antitrust claims alternatively as a weapon and as a shield, and a significant additional tool in the antitrust enforcement portfolio ${ }^{158}$.

Thirdly, as has been stressed in this paper, as the Directive leaves room for the national remedial/procedural autonomy, MS' idiosyncratic rules in MS legal systems which do not contravene the principle of effectiveness will continue to exist and be applied. Together with the fragmented and incomplete harmonization of the Directive this means that a fully level playing field for damages claims is inconceivable and interested parties will continue to be able to select to litigate their claims in different MS, where they may perceive advantages.

Finally, it remains to be seen how the new rules adopted by MS in compliance with the Directive will enhance or promote damages claims and private enforcement of competition law in general. The Directive will ultimately be regarded as a successful measure if it has a positive impact in increasing the amount of successful damages claims in the MS national courts.

\footnotetext{
${ }^{157}$ See “'One bird in the hand...' The Directive on damages actions for breach of the competition rules” (2014) Common Market Law Review 51: 1333-1342.

158 See David J Gerber “Private Enforcement of competition law: a comparative perspective” in Thomas M. J. Möllers \& Andreas Heinemann (eds) The Enforcement of Competition Law in Europe, Cambridge University Press 2007, 450-451.
} 


\section{References}

Arianna Andreangeli "From Complainant to Private Attorney General : The Modernisation of EU Competition Enforcement and Private Antitrust Action before National Courts” in Michael Dougan \& Samantha Currie (eds.) 50 years of the European Treaties: Looking Back and Thinking Forward, Hart 2008, 229-254.

David Ashton \& David Henry Competition Damages Actions in the EU. Law \& Practice, Elgar 2013.

Philip Bentley QC \& David Henry “Antitrust Damages Actions: Obtaining Probative Evidence in the Hands of Another Party” (2014) World Competition 37/3: 271-292.

Ulf Bernitz “Introduction to the Directive on Competition Damages Actions” in Maria Bergström, Marios Iacovides \& Magnus Strand (eds.) Harmonising EU Competition litigation. The New Directive and Beyond, Hart 2016, 3-13.

Roger D. Blair \& Wenche Wang “Buyer Cartels and private enforcement of antitrust policy” (2017) Managerial Decision Economics 38: 1185-1192.

Robert G. Bone “Discovery” in Gerrit De Geest \& Chris W. Sanchirico (ed) Encyclopedia of Law and Economics, Vol. 7 (Tort Law and Economics), Elgar 2007, 188-202.

Miriam C. Buiten, Peter Van Wijck \& Jan Kees Winters “Does the European Damages Directive Make Consumers Better Off? (2018) Journal of Competition Law \& Economics 14/1:91-104.

Vlatka Butorac Malnar “The Kone Case: A Missed Opportunity to Put the Standard of Causation Under the Umbrella of the EU” in Vesna Tomljenović, Nada Bodiroga-Vukobrat, Vlatka Butorac Malnar, Ivana Kunda Tomljenović, Bodiroga-Vukobrat, Butorac Malnar, Kunda (eds.)_EU Competition and State Aid Rules: Public and Private Enforcement 2017, 175-195.

Eckard Bueren \& Florien Smuda “Suppliers to a sellers' cartel and the boundaries of the right to damages in U.S. versus EU competition law” (2017) European Journal of Law \& Economics 1-41.

Anca D. Chirita “The Disclosure of Evidence under the 'Antitrust Damages’ Directive 2014/104/EU” in Tomljenović, Bodiroga-Vukobrat, Butorac Malnar, Kunda (eds.) EU Competition and State Aid Rules, 147-173.

“" One bird in the hand...' The Directive on damages actions for breach of the competition rules” (2014) Common Market Law Review 51: 1333-1342.

Bernardo Cortese "Defining the Role of Courts and Administrative Bodies in Private Enforcement in Europe: United in Diversity?” in Bernardo Cortese (ed) EU Competition Law. Between Public and Private Enforcement, Wolters 2014, 145-172.

Mihail Danov 6 Florian Becker “Introduction: The Enforcement Pattern Shaping Litigants' Strategies” in Mihail Danov, Florian Becker \& Paul Beaumont (eds) Cross-Border EU Competition Law Actions, Hart 2013, 143-147 
Niamh Dunne “Antitrust and the Making of European Tort Law” Oxford Journal of Legal Studies 2015: 1-134.

-“Courage and compromise: the Directive on Antitrust Damages” (2015) European Law Review 40/4: $\underline{581-597 .}$

-“The Role of Private Enforcement Within EU Competition Law” Cambridge Yearbook of European Legal Studies 2014, 143-187.

Elizabeth Eklund "Indirect Purchasers- Is there anything new in the Directive? An Introductory Overview of the Current and Future Status of Indirect Purchaser in the EU” in Berstrong, Iacovides \& Strand (eds) Harmonisng EU Competition Litigation, 261-278.

Gerda Falkner, Miriam Hartlapp, Simone Leiber \& Oliver Treib "Non-Compliance with EU Directives in the Member States: Opposition through the Backdoor?” (2004) West European Politics 27/3: 452-473.

David J Gerber "Private Enforcement of competition law: a comparative perspective” in Thomas M. J. Möllers \& Andreas Heinemann (eds) The Enforcement of Competition Law in Europe, Cambridge University Press 2007, 431-452.

Xavier Groussot \& Justin Pierce “Transparency and Liability in Leniency Programmes: A Question of Balancing” in Bersgtröm, Iacovides \& Strand (eds) Harmonising EU Competition Litigation, 143163.

Katri Havu "Causation and Damage: What the Directive Does Not Solve and Remarks on Relevant EU Law” in Vladimir Bastidas, Marios Iacovides and Magnus Strand (eds) Competition Damages Directive, First Experiences of the New Regime, Hart 2018 (forthcoming).

-“EU Law in Member State Courts: ‘Adequate Judicial Protection’ and Effective Application: Ambiguities and Non-sequiturs in Guidance by the Court of Justice?” (2016) Contemporary Readings $\quad$ in Law and Social Justice 8/1:158-187.

-“Quasi-coherence by Harmonisation of EU Competition Law-related Damages Actions?” in Pia Letto-Vanamo \& Jan Smits (eds) Coherence and Fragmentation in European Private Law, Verlag Dr Otto Schmidt 2012, 25-42.

Anneli Howard, “Too little, too late? The European Commission’s Legislative Proposals on AntiTrust Damage Actions” (2014) Journal of European Competition Law \& Practice 4/6: 455-465.

“The draft Directive on competition law damages - what does it mean for infringers and victims?” (2014) European Competition Law Review 35:51-55.

Kai Hüschelrath \& Sebastian Peyer "Public and Private Enforcement of Competition Law: A Differentiated Approach” (2013) World Competition 36/4: 585-610.

Marios C. Iacovides “The Presumption and Quantification of Harm in the Directive and the Practical 
Guide” in Bersgtröm, Iacovides \& Strand (eds) Harmonising EU Competition Litigation, The EU Directive and beyond, 2016, 295-313.

Maria Ioannidou Consumer involvement in Private EU Competition Law Enforcement, Oxford University Press 2015.

Alison Jones "Private Enforcement of EU Competition Law: A Comparison with, and Lessons from, the US” in Bersgtröm, Iacovides \& Strand (eds) Harmonising EU Competition Litigation, 15-41.

Žygimantas Juška "The Effectiveness of Antitrust Collective Litigation in the European Union: A Study of the Principle of Full Compensation” (2017) International Review of Intellectual Property \& Competition Law 49/1: 63-93.

Christian Kersting "Removing the Tension Between Public and Private Enforcement: Disclosure and Privileges for Successful Leniency Applicants” (2014) Journal of European Competition Law \& Practice 5/1: 2-5.

Carsten Koenig "Making contribution work: the liability of privileged and non-privileged injurers in EU competition law” (2018) European Competition Journal 14 (forthcoming).

Assimakis P. Komminos “Civil Antitrust Remedies Between Community and National Law” in Catherine Barnard \& Okeoghene Odudu (eds.) The Outer Limits of European Union Law, Hart 2009, 363-400.

- "Effect of Commission Decisions on Private Antitrust Litigation: Setting the Story Straight” (2007) Common Market Law Review 44: 1387-1428.

Jeroen Kortmann \& Rein Wesseling “Two Concerns Regarding the European Draft Directive On Antitrust Damage Actions” (2013) CPI Antitrust Chronicle, Aug. 2013 (1), 1-9

Richard Král “On the choice of methods of transposition of EU Directives” (2016) European Law Review 41/2: 220-242.

Rainer Kulms “Competition Law Enforcement under informational Asymmetry” China-EU Law Journal 5: 209-231.

Robert H. Lande \& Joshua P. Davis "Benefits From Private Antitrust Enforcement: An Analysis of Forty Cases” (2008) University of San Francisco Law Review 42: 879-918.

Björn Lundqvist \& Helene Andersson “Access to Documents for Cartel Victims and Cartel Members- Is the System Coherent?” in Bergström, Iacovides \& Strand (eds.) Harmonising EU Competition litigation, 165-184.

Mark-Oliver Mackenrod "Private incentive, optimal deterrence and Damage claims for Abuses of Dominant Positions- The Interaction between the Economic Review of the Prohibition of Abuses of Dominant Position and Private Enforcement“ in Mark-Oliver Mackenrodt, Beatriz Conde Gallego \& 
Stefan Enchelmaier (ed.) Abuse of Dominant Position: New Interpretation, New Enforcement Mechanisms?, Springer 2008, 165-189.

Franck P. Maier-Rigaud “Toward a European Directive on Damages Actions” (2014) Journal of Competition Law \& Economics 10/2: 341-360.

Frank P. Maier-Rigaud \& Ulrich Schwalbe “Quantification of Antitrust Damages” in David Ashton \& David Henry Competition Damages Actions in the EU. Law \& Practice, Elgar 2013, 210-262.

Francisco Marcos \& Albert Sánchez Graells “Towards a European Tort Law-Damages Actions for Breach of the EC Antitrust Rules: Harmonizing Tort Law through the Back Door” (2008) European Review of Private Law 3-2008: 469-488.

Anthony Maton, Vijaiya Poopalasingam, Marc Kuijper \&Timo Angerbauer "The Effectiveness of National Fora in Europe for the Practice of Antitrust Litigation” (2011) Journal of European Competition Law \& Practice 2/5: 489-508.

Massimo Merola \& Leonardo Armati “The Binding Effect of NCA Decisions under the Damages Directive: Rationale and Practical Implications” (2016) Italian Antitrust Review 3/1: 87-108.

Caterina Migani “Directive 2014/104/EU: In Search of a Balance between the Protection of Leniency Corporate Statements and an Effective Private Competition Law Enforcement” (2014) Global Antitrust Review 81-111.

Okeoghene Odudu \& Albert Sánchez Graells “The interface of EU and national tort law” in Paula Giliker (ed) Research Handbook on European Tort Law, Elgar 2017, 154-183.

Sofia Oliveira Pais and Anna Piszcz "Package on Actions for Damages Based on Breaches of EU Competition Rules: Can One Size Fit All?” (2014) Yearbook of Antitrust and Regulatory Studies 7/10: 209-234.

Lorenzo Pace “The Court of Justice 'Antitrust Enforcement Negative Harmonisation Framework’ and the CDC and Pfleiderer judgments: 'Another Brick in the Wall'” in Cortese (ed) EU Competition Law. Between Public and Private Enforcement, 241-255.

Evelin Pärn-Lee "Effect of National Decisions on Actions for Competition Damages in the CEE Countries” (2017) Yearbook of Antitrust and Regulatory Studies 10/15: 177-198.

Sebastian Peyer “Compensation and the Damages Directive” (2016) European Competition Journal 12/1: 87-112.

- “The Antitrust Damages Directive -much ado about nothing?” in Mel Marquis \& Roberto Cisotta (ed.) Litigation and Arbitration in EU Law, Elgar 2015, 33-46.

- “Access to competition authorities' files in private antitrust litigation” (2015) Journal of Antitrust Enforcement 3: 58-86. 
- “Cartel Members Only- Revisiting Private Antitrust Enforcement in Europe” (2011) International \& Comparative Law Quarterly 60/3: 627-657.

Anna Piszcz "Room for manoeuvre for Member States: Issues for decision on the occasion of the transposition of the Damages Directive” (2017) Market \& Competition Law Review 1/1: 81-109.

-“Piecemeal Harmonisation Through the Damages Directive? Remarks on What Received Too Little Attention in Relation to Private Enforcement of EU Competition Law” (2015) Yearbook of Antitrust and Regulatory Studies 8/12:79-98.

Barry J. Rodger "Why Not court? A Study of follow-on actions in the UK” (2013) Journal of Antitrust Enforcement 1:104-131.

Daniel L. Rubinfield “An Empirical Perspective on Legal Process: Should Europe. Introduce Private Antitrust Enforcement?” in Peter Nobel \& Marin Gets (eds.) New Frontiers in Law and Economics, Schulthes 2006, 141-149.

Magnus Strand “Labours of Harmony: unresolved issues in competition damages” (2017) European Competition Law Review 38: 204-208.

- “Beyond the Competition Damages Directive: What Room for Competition Law Restitution?” in Bersgtröm, Iacovides \& Strand (eds) Harmonising EU Competition Litigation, 279-293.

Bernard Steunenberg \& Mark Rhinard "The transposition of European law in EU member states: between process and politics” (2010) European Political Science Review 2/3: 495-520

Thomas Thiede "Fine to follow-on? Private anti-trust actions in European Law” (2017) China Antitrust Law Journal 5: 233-263.

Emmanuela Truli “Will Its Provisions Serve Its Goals? Directive 2014/104/EU on Certain Rules Governing Actions for Damages for Competition Law Infringements” 2016 Journal of European Competition Law \& Practice 7/5: 299-312.

Pieter Van Cleynenbreugel "Embedding Procedural Autonomy: The Directive and National Procedural Rules” in Bergström, Iacovides \& Strand (eds.) Harmonising EU Competition litigation, 99-119.

Roger Van den Bergh \& Sonja Keske "Private Enforcement of European Competition Law: Quo Vadis?” (2008) European Review of Contract Law 3/4: 468-486.

Anna Wallerman "Towards an EU Law Doctrine on the Exercise of Discretion in National Courts? The Member States' Self Imposed Limits on National Procedural Autonomy” (2016) Common Market Law Review 53: 339-360.

Folkert G. Willman “The end of absence: the growing body of EU legislation on private enforcement and the main remedies it provides for” (2016) Common Market Law Review 53: 887-936, 2016. 
- Private Enforcement of EU Law before National Courts. The EU legislative framework, Elgar 2015.

Katryn Wright “The Ambit of Judicial Competence after the EU Antitrust Damages Directive” (2016) Legal Issues of Economic Integration 43/1: 15-40.

Wolfgang Wurmnest "International jurisdiction in competition damages cases under the Brussels I Regulation: CDC Hydrogen Peroxide” (2016) Common Market Law Review 53: 235-236.

- "Private Antitrust Litigation in Germany after the Reform of the Law against Restraints of Competition” (2005) German Law Journal 6/8: 1173-1189. 